\title{
Biotransformation of Neoruscogenin by the Endophytic Fungus Alternaria eureka
}

\author{
Özge Özçınar, ${ }^{\dagger}$ Özgür Tağ, ${ }^{\ddagger}$ Hasan Yusufoglu, ${ }^{\S}$ Bijen Kivçak, ${ }^{\dagger}$ and Erdal Bedir*, ${ }^{*} \odot$ \\ ${ }^{\dagger}$ Department of Pharmacognosy, Faculty of Pharmacy, Ege University, 35100 Bornova-İzmir, Turkey \\ ${ }^{\ddagger}$ Bionorm Natural Products Production \& Marketing Corp., İTOB, 35477 Menderes-İzmir, Turkey \\ ${ }^{\S}$ Department of Pharmacognosy, College of Pharmacy, Prince Sattam Bin Abdulaziz University, 11942 Al-Kharj, Saudi Arabia \\ ${ }^{\perp}$ Department of Bioengineering, Faculty of Engineering, Izmir Institute of Technology, 35430 Urla-Izmir, Turkey
}

\section{Supporting Information}

\begin{abstract}
Biotransformation of neoruscogenin (NR, 1, spirosta-5,25(27)-diene- $\beta, 3 \beta$-diol), the major bioactive sapogenin of Ruscus preparations, was carried out with the endophytic fungus Alternaria eureka. Fourteen new biotransformation products $(\mathbf{2}-\mathbf{1 5})$ were isolated, and their structures were elucidated by NMR and HRESIMS data analyses. A. eureka affected mainly oxygenation, oxidation, and epoxidation reactions on the $B$ and $C$ rings of the sapogenin to afford compounds 8-15. In addition to these, cleavage of the spiroketal system as in compounds $2-7$ and subsequent transformations provided unusual metabolites. This is the first

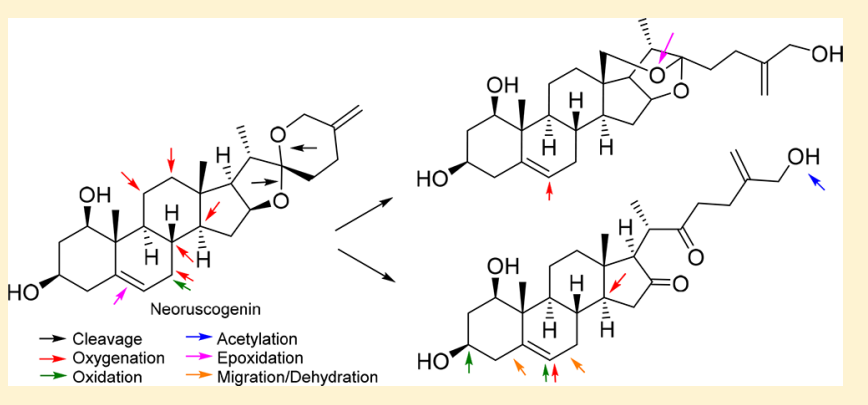
study reporting conversion of the spirostanol skeleton to cholestane-type metabolites $\mathbf{2}-\mathbf{5}$. Additionally, the cleavage of the C22/C-26 oxygen bridge yielding a furostanol-type steroidal framework and subsequent formation of the epoxy bridge between C18 and C-22 in 7 was encountered for the first time in steroid chemistry.
\end{abstract}

$\mathrm{T}_{\mathrm{k}}^{\mathrm{k}}$ he natural product drug discovery process involves isolation of new metabolites from natural sources, investigation of their biological activities, and semisynthesis of more active analogues. Compared to chemical methods microbial biotransformation is advantageous for preparing new oxygenated steroid derivatives due to the stereo- and regioselective reaction capability and its operation under mild conditions. $^{1-4}$ In addition to overcoming the problems confronted in chemical synthesis, this process can be of assistance to establish biosynthetic pathways, increase/decrease the bioactivity/toxicity profiles of the lead molecules, or support structure-activity relationship studies. Moreover, it is a useful method to predict drug metabolism due to the similarity of the enzyme systems of fungi and mammalians. 5,6

Endophytic organisms are bacterial or fungal microorganisms that colonize internal tissues of living plants without causing any disease symptoms, and they constitute one of the most exciting groups of microorganisms. They have attracted a great deal of attention due to their ability to produce novel bioactive secondary metabolites for many years. ${ }^{7-9}$ While producing interesting chemistry, they are also able to interact with their hosts via special enzymes and chemicals, which make them useful sources as biocatalysts. ${ }^{10-15}$

Neoruscogenin $(\mathrm{NR}, \mathbf{1})$ is one of the major spirostanol steroids of Ruscus aculeatus (Butcher's broom, Rusci rhizome, Asparagaceae). The powdered roots, extracts, and the mixture of the major bioactive steroidal sapogenins ruscogenins [mixture of two major sapogenins, viz., neoruscogenin (1) and ruscogenin] are components of various pharmaceutical preparations to treat chronic venous insufficiency, varicose veins, hemorrhoids, and orthostatic hypotension due to their pharmacological activities. ${ }^{16-24}$ The European Pharmacopoeia prescribes "not less than $1.0 \%$ of total sapogenins expressed as ruscogenins (neoruscogenin and ruscogenin mixture)", and the European Scientific Cooperative on Phytotherapy recommends oral use of $7-11 \mathrm{mg} /$ day. $^{25,26}$

Despite several reported semisynthesis and biotransformation studies of steroids, studies performed on ruscogenin have so far been limited, ${ }^{27-30}$ and there has been neither an in vitro nor in vivo report on NR revealing its metabolic fate. In order to shed light into the metabolism of neoruscogenin (1), estimate its likely mammalian metabolites, and investigate the potential use of endophytes as biocatalyst, we herein report biotransformation of NR by the endophytic fungus Alternaria eureka. As a result, 14 biotransformation products $(2-15)$ were purified from the biotransformation broth by extensive chromatographic procedures. The structures of the metabolites were elucidated by NMR and HRESIMS data analyses. A. eureka affected mainly the anticipated oxygenation, oxidation, and epoxidation reactions to afford compounds 8-15, whereas cleavage of the spiroketal system resulted in exceptional transformation products $2-7$.

Received: November 8, 2017

Published: June 12, 2018 


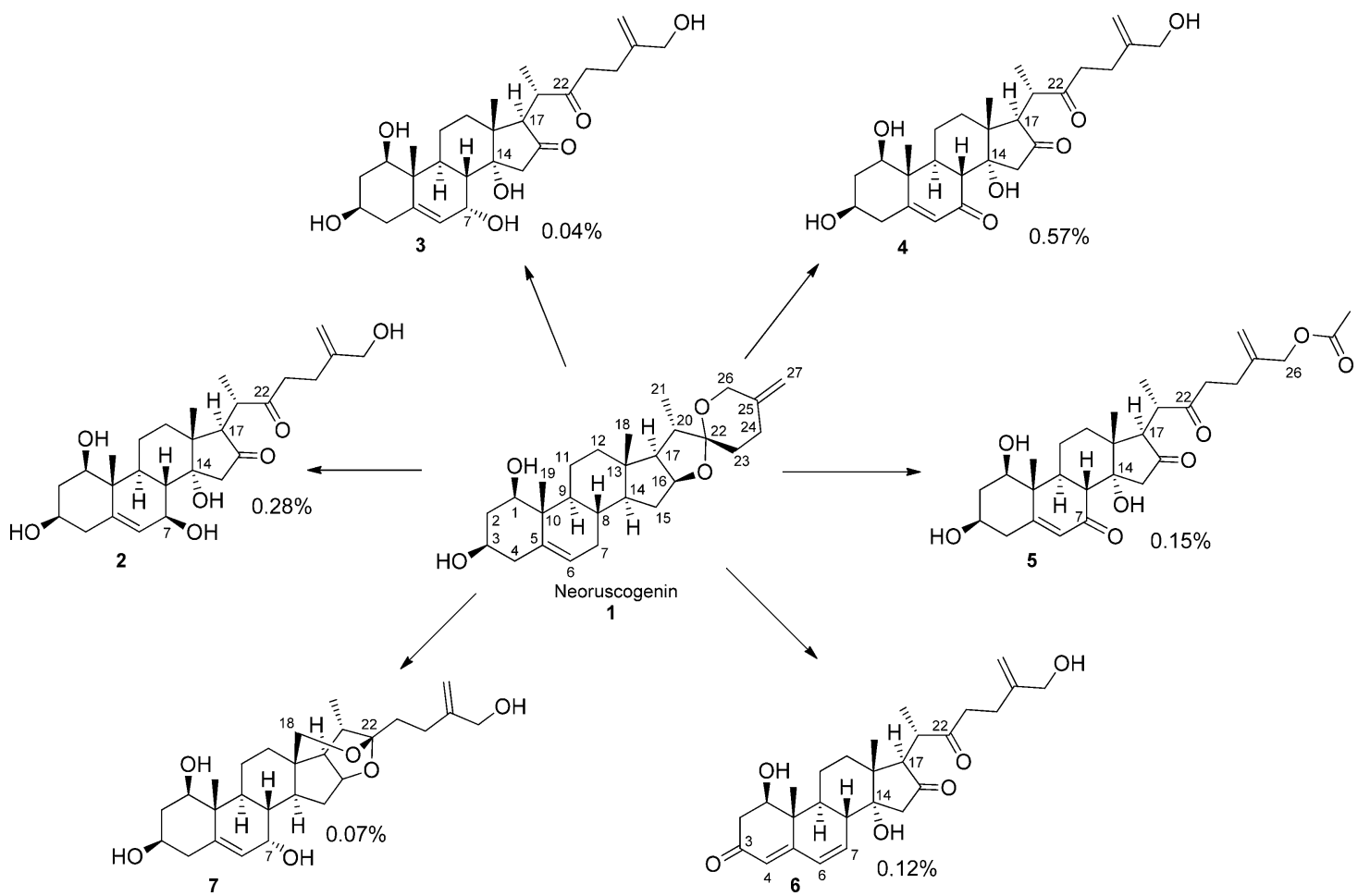

Figure 1. Structures and yields of the cholestane- (2-6) and furostanol-type (7) biotransformation products.

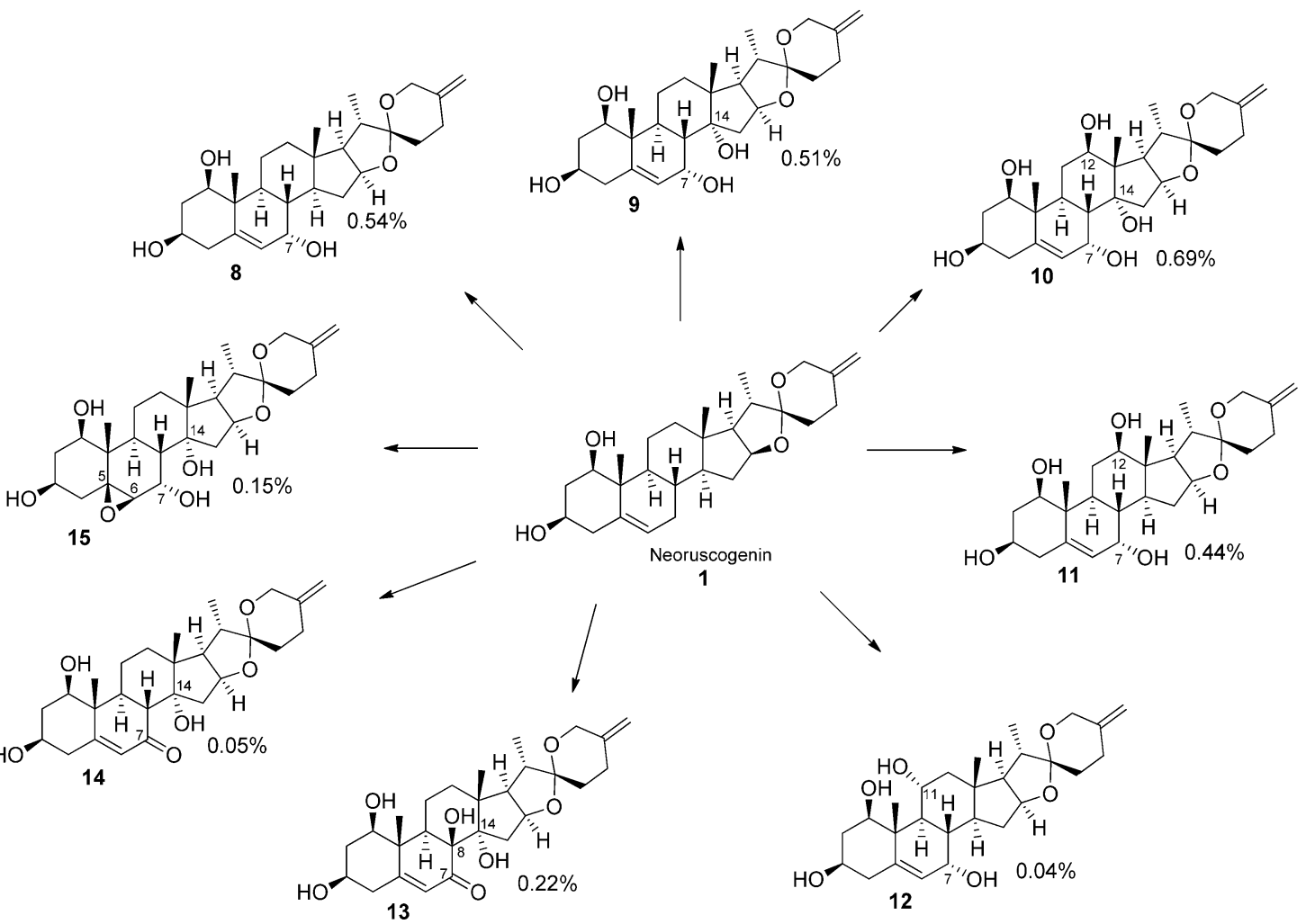

Figure 2. Structures and yields of the spirostanol-type biotransformation products (8-15).

\section{RESULTS AND DISCUSSION}

The literature survey and preliminary screening studies have prompted the use of the endophytic fungus $A$. eureka as biocatalyst to transform the steroidal sapogenin neoruscogenin (1). After 10 days of incubation, 14 metabolites (2-15)
(Figures 1 and 2) were isolated from the broth, and the structures were elucidated by means of $1 \mathrm{D}$ and $2 \mathrm{D}$ NMR and HRMS experiments. The ${ }^{1} \mathrm{H}$ and ${ }^{13} \mathrm{C}$ NMR spectroscopic data of the compounds are collated in Tables $1-3$.

The sodium adduct ion at $m / z 499.2653[\mathrm{M}+\mathrm{Na}]^{+}$(calcd 499.2671 for $\mathrm{C}_{27} \mathrm{H}_{40} \mathrm{O}_{7} \mathrm{Na}$ ) in the HRESIMS spectrum of 2 
Table 1. ${ }^{1} \mathrm{H}$ and ${ }^{13} \mathrm{C}$ NMR Data of Compounds (2-6) (500 MHz, in Pyridine- $d_{5}$ )

\begin{tabular}{|c|c|c|c|c|c|c|c|c|c|c|}
\hline \multirow[b]{2}{*}{ position } & \multicolumn{2}{|r|}{2} & \multicolumn{2}{|r|}{3} & \multicolumn{2}{|r|}{4} & \multicolumn{2}{|r|}{5} & \multicolumn{2}{|r|}{6} \\
\hline & $\delta_{\mathrm{C}}$ & $\delta_{\mathrm{H}}(J$ in $\mathrm{Hz})$ & $\delta_{\mathrm{C}}$ & $\delta_{\mathrm{H}}(J$ in $\mathrm{Hz})$ & $\delta_{\mathrm{C}}$ & $\delta_{\mathrm{H}}(J$ in $\mathrm{Hz})$ & $\delta_{\mathrm{C}}$ & $\delta_{\mathrm{H}}(J$ in $\mathrm{Hz})$ & $\delta_{\mathrm{C}}$ & $\delta_{\mathrm{H}}(J$ in $\mathrm{Hz})$ \\
\hline 1 & 77.2 & $3.84 \mathrm{~d}(11.5)$ & 77.5 & $3.82 \mathrm{~m}$ & 76.2 & $3.83 \mathrm{~m}$ & 76.2 & $3.87 \mathrm{~d}(11.0)$ & 72.5 & $\begin{array}{l}4.27 \text { ddd }(5.5 \text {, } \\
\quad 6.0,6.0)\end{array}$ \\
\hline 2 & 43.7 & $2.27 \mathrm{~m}, 2.65 \mathrm{~m}$ & 42.8 & $\begin{array}{l}2.24 \text { ddd }(11.5,12.0 \\
12.0), 2.53 \mathrm{~m}\end{array}$ & 42.9 & $\begin{array}{l}2.27 \mathrm{dd}(11.5,12.0) \\
2.62 \mathrm{~m}\end{array}$ & 43.4 & $\begin{array}{l}2.29 \text { ddd }(11.5,12.0 \\
12.0), 2.65 \mathrm{~m}\end{array}$ & 44.9 & $\begin{array}{l}2.99 \mathrm{~m} \\
3.05 \mathrm{~m}\end{array}$ \\
\hline 3 & 67.7 & $3.95 \mathrm{~m}$ & 67.3 & $3.84 \mathrm{~m}$ & 66.1 & $3.93 \mathrm{~m}$ & 66.0 & $3.91 \mathrm{~m}$ & 197.7 & \\
\hline 4 & 43.6 & $2.70 \mathrm{~m}$ & 43.7 & $2.74-2.78 \mathrm{~m}$ & 43.6 & $2.76 \mathrm{~m}$ & 43.6 & $2.75 \mathrm{~m}$ & 124.3 & $5.93 \mathrm{~s}$ \\
\hline 5 & 140.2 & & 143.9 & & 166.0 & & 166.2 & & 162.8 & \\
\hline 6 & 131.0 & $5.97 \mathrm{~s}$ & 126.1 & $5.93 \mathrm{~d}(4.5)$ & 128.2 & $6.04 \mathrm{~s}$ & 128.2 & $6.03 \mathrm{~s}$ & 130.1 & $\begin{array}{l}6.30 \mathrm{dd}(1.0 \\
9.5)\end{array}$ \\
\hline 7 & 66.7 & $4.96 \mathrm{bs}$ & 66.1 & $4.32 \mathrm{~s}$ & 200.1 & & 200.5 & & 140.1 & $\begin{array}{l}6.25 \mathrm{dd}(1.0 \\
9.5)\end{array}$ \\
\hline 8 & 43.6 & $2.27 \mathrm{~m}$ & 37.9 & $1.95 \mathrm{~m}$ & 48.3 & $2.87 \mathrm{~m}$ & 48.3 & $2.86 \mathrm{~m}$ & 41.3 & $2.89 \mathrm{~m}$ \\
\hline 9 & 42.9 & $\begin{array}{l}2.55 \text { ddd }(5.0, \\
5.0,11.5)\end{array}$ & 38.2 & $2.77 \mathrm{~m}$ & 44.8 & $2.94 \mathrm{~m}$ & 44.8 & $2.94 \mathrm{~m}$ & 44.7 & $2.61 \mathrm{~m}$ \\
\hline 10 & 43.2 & & 44.1 & & 44.8 & & 44.8 & & 42.4 & \\
\hline 11 & 22.9 & $1.95 \mathrm{~m}, 2.99 \mathrm{~m}$ & 22.7 & $1.93 \mathrm{~m}, 2.92 \mathrm{~m}$ & 23.0 & $\begin{array}{l}1.99 \text { ddd }(13.0,12.0 \text {, } \\
12.5), 2.92 \mathrm{~m}\end{array}$ & 23.1 & $1.99 \mathrm{~m}, 2.92 \mathrm{~m}$ & 23.3 & $\begin{array}{l}1.99 \mathrm{~m}, \\
2.55 \mathrm{~m}\end{array}$ \\
\hline 12 & 31.4 & $\begin{array}{l}1.70 \mathrm{~d}(12.0) \\
2.67 \mathrm{~m}\end{array}$ & 31.4 & $1.60 \mathrm{~m}, 2.72 \mathrm{~m}$ & 30.9 & $\begin{array}{l}1.68 \mathrm{~d}(12.5) \\
2.62 \mathrm{~m}\end{array}$ & 30.8 & $1.67 \mathrm{~m}, 2.61 \mathrm{~m}$ & 31.5 & $\begin{array}{l}1.70 \mathrm{~m} \\
2.53 \mathrm{~m}\end{array}$ \\
\hline 13 & 46.1 & & 46.0 & & 46.6 & & 45.6 & & 46.0 & \\
\hline 14 & 78.4 & & 79.7 & & 77.1 & & 77.1 & & 78.6 & \\
\hline 15 & 49.8 & $\begin{array}{l}3.20 \mathrm{~d}(18.5) \\
3.05 \mathrm{~d}(18.5)\end{array}$ & 47.5 & $\begin{array}{l}2.49 \mathrm{~d}(17.5), 2.64 \mathrm{~d} \\
\quad(17.5)\end{array}$ & 49.2 & $\begin{array}{l}2.75 \mathrm{~m}, 3.59 \mathrm{~d} \\
(19.2)\end{array}$ & 49.2 & $3.57 \mathrm{~m}$ & 46.3 & $\begin{array}{l}2.60 \mathrm{~m} \\
2.75 \mathrm{~m}\end{array}$ \\
\hline 16 & 220.1 & & 218.7 & & 219.3 & & 219.4 & & 217.9 & \\
\hline 17 & 60.2 & $3.92 \mathrm{~d}(11.0)$ & 60.7 & $3.89 \mathrm{~d}(11.0)$ & 59.5 & $3.87 \mathrm{~d}(11.0)$ & 59.6 & $3.87 \mathrm{~d}(11.0)$ & 60.6 & $3.94 \mathrm{~d}(13.0)$ \\
\hline 18 & 16.6 & $1.07 \mathrm{~s}$ & 16.3 & $1.00 \mathrm{~s}$ & 16.9 & $1.01 \mathrm{~s}$ & 17.2 & $1.02 \mathrm{~s}$ & 17.2 & $1.07 \mathrm{~s}$ \\
\hline 19 & 13.4 & $1.41 \mathrm{~s}$ & 12.9 & $1.37 \mathrm{~s}$ & 12.1 & $1.50 \mathrm{~s}$ & 12.1 & $1.50 \mathrm{~s}$ & 11.4 & $1.40 \mathrm{~s}$ \\
\hline 20 & 43.7 & $2.80 \mathrm{~m}$ & 43.4 & $2.75 \mathrm{~m}$ & 43.4 & $2.74 \mathrm{~m}$ & 43.5 & $2.77 \mathrm{~m}$ & 43.7 & $2.80 \mathrm{~m}$ \\
\hline 21 & 15.7 & $1.08 \mathrm{~d}(5.5)$ & 15.6 & $1.05 \mathrm{~d}(7.0)$ & 15.6 & $1.06 \mathrm{~d}(5.6)$ & 15.3 & $1.08 \mathrm{~d}(6.5)$ & 15.5 & $1.06 \mathrm{~d}(7.0)$ \\
\hline 22 & 212.9 & & 212.6 & & 212.8 & & 212.8 & & 212.5 & \\
\hline 23 & 40.8 & $\begin{array}{c}3.00 \mathrm{~m}, 3.13 \mathrm{dd} \\
(7.5,8.5)\end{array}$ & 40.7 & $3.00 \mathrm{~m}, 3.15 \mathrm{~m}$ & 40.8 & $2.95 \mathrm{~m}, 3.16 \mathrm{~m}$ & 40.3 & $2.93 \mathrm{~m}, 3.09 \mathrm{~m}$ & 40.8 & $\begin{array}{l}3.00 \mathrm{~m}, \\
3.13 \mathrm{~m}\end{array}$ \\
\hline 24 & 27.0 & $2.70 \mathrm{~m}$ & 27.1 & $2.74 \mathrm{~m}$ & 27.0 & $2.72 \mathrm{~m}$ & 26.9 & $2.57 \mathrm{~m}$ & 27.1 & $2.22 \mathrm{~m}(2 \mathrm{H})$ \\
\hline 25 & 150.1 & & 150.2 & & 150.1 & & 144.2 & & 150.2 & \\
\hline 26 & 65.2 & $4.39 \mathrm{~s}$ & 65.2 & $4.40 \mathrm{~s}$ & 65.2 & $4.39 \mathrm{~s}$ & 66.9 & $4.69 \mathrm{~s}$ & 65.3 & $4.41 \mathrm{~s}$ \\
\hline 27 & 108.3 & $5.07 \mathrm{~s}, 5.42 \mathrm{~s}$ & 108.2 & $5.08 \mathrm{~s}, 5.43 \mathrm{~s}$ & 108.3 & $5.43 \mathrm{~s}, 5.08 \mathrm{~s}$ & 112.0 & $5.07 \mathrm{~s}, 5.13 \mathrm{~s}$ & 107.9 & $5.09 \mathrm{~s}, 5.43 \mathrm{~s}$ \\
\hline$\underline{\mathrm{COCH}}_{3}$ & & & & & & & 170.4 & $2.00 \mathrm{~s}$ & & \\
\hline $\mathrm{COCH}_{3}$ & & & & & & & 20.5 & & & \\
\hline
\end{tabular}

indicated eight indices of hydrogen deficiency, a $48 \mathrm{amu}$ increase over 1 . The ${ }^{13} \mathrm{C}$ NMR and DEPT135 spectra showed two carbonyl signals at $\delta_{\mathrm{C}} 212.9$ and 220.1, two resonances of a disubstituted olefinic system $\left(\delta_{\mathrm{C}} 108.3, \mathrm{t} ; 150.1, \mathrm{~s}\right)$, and signals of a trisubstituted olefinic system $\left(\delta_{\mathrm{C}} 131.0, \mathrm{~d} ; 140.2, \mathrm{~s}\right)$ that revealed a tetracyclic framework for 2, suggesting ring cleavage(s). Based on the absence of the characteristic spiroketal carbon resonance (C-22, ca. $110 \mathrm{ppm}$ ) and the characteristic H-16 signal, the low-field shift of the exocyclic $\mathrm{H}_{2}-27$ resonances (ca. $0.5 \mathrm{ppm}$ ), and replacement of the characteristic AB-system signal of $\mathrm{H}_{2}-26$ with an oxymethylene singlet, the aforementioned cleavage was evident. Thus, it was inferred that the spirostanol skeleton was transformed into a steroidal derivative with an acyclic side chain. The DEPT-135, ${ }^{13} \mathrm{C}$ NMR, and HSQC spectra showed two additional low-field signals at $\delta_{\mathrm{C}} 78.4(\mathrm{~s})$ and 66.7 (d). The former carbon displayed a long-range $\mathrm{HMBC}$ cross-peak with an exchangeable proton resonating at $\delta_{\mathrm{H}} 6.48$ (Figure 3), indicative of hydroxylation of a methine carbon of 1 . Examination of the COSY and TOCSY spectra led to identification of five main spin systems (SS1-SS5) in 2. One of these spin systems, SS-2 $\left[\mathrm{H}-6 \rightarrow \mathrm{H}-7(\mathrm{O}) \rightarrow \mathrm{H}-8 \rightarrow \mathrm{H}-9 \rightarrow \mathrm{H}_{2}-11 \rightarrow \mathrm{H}_{2}-12\right]$, located one of the hydroxy groups at C-7. The deshielding of $\mathrm{H}-7\left(\delta_{\mathrm{H}}\right.$ 4.96) due to the $\Delta^{5(6)}$ double bond was also noteworthy. The simplified $\mathrm{H}-17$ spin system evident in the COSY spectrum and the 1.00 ppm deshielding of $\mathrm{H}-17\left(\delta_{\mathrm{H}} 3.92, \mathrm{~d}, J=11.0 \mathrm{~Hz}\right)$ compared to 1 implied the presence of a carbonyl group at $\mathrm{C}$ 16. In the $\mathrm{HMBC}$ spectrum, the carbonyl resonating at $\delta_{\mathrm{C}}$ 220.1 (C-16) displayed correlations with $\mathrm{H}-17$ and protons of a methylene group $\left(\mathrm{H}_{2}-15\right)$ resonating as an $\mathrm{AB}$ system $\left(\delta_{\mathrm{H}} 3.20\right.$ and 3.05, both $\left.\mathrm{d}, J_{\mathrm{AB}}=18.5 \mathrm{~Hz}\right)$. The isolated C-15 methylene protons indicated functionalization at $\mathrm{C}-14$. The HMBC correlation of the carbon at $\delta_{\mathrm{C}} 78.4(\mathrm{~s})$ and $\mathrm{H}_{3}-18$ defined the location of the second hydroxy group at C-14. The spin systems and their interconnectivities secured by the 2D NMR spectra permitted establishment of the tetracyclic skeleton from $\mathrm{C}-1$ to $\mathrm{C}-21$. The aforementioned conclusions left the C-22 $\rightarrow$ C-27 system to be identified. The HMBC correlation of the second carbonyl signal $\left(\delta_{\mathrm{C}} 212.9\right)$ with $\mathrm{H}_{3}-21\left(\delta_{\mathrm{H}} 1.08, \mathrm{~d}, J=\right.$ $5.5 \mathrm{~Hz})$ and $\mathrm{H}-20\left(\delta_{\mathrm{H}} 2.80\right)$ verified that $\mathrm{C}-22$ was also oxygenated after cleavage of the spiroketal system to produce the C-22 carbonyl group. Inspection of the COSY spectrum revealed another spin system (SS-4) including two methylene groups, which was readily assigned to $\mathrm{H}_{2}-23$ and $\mathrm{H}_{2}-24$ based 
Table 2. ${ }^{1} \mathrm{H}$ and ${ }^{13} \mathrm{C}$ NMR Data of Compounds 7-11 (500 MHz, in Pyridine- $d_{5}$ )

\begin{tabular}{|c|c|c|c|c|c|c|c|c|c|c|}
\hline \multirow[b]{2}{*}{ position } & \multicolumn{2}{|r|}{7} & \multicolumn{2}{|r|}{8} & \multicolumn{2}{|r|}{9} & \multicolumn{2}{|r|}{10} & \multicolumn{2}{|r|}{11} \\
\hline & $\delta_{\mathrm{C}}$ & $\delta_{\mathrm{H}}(J$ in $\mathrm{Hz})$ & $\delta_{\mathrm{C}}$ & $\delta_{\mathrm{H}}(\mathrm{J}$ in $\mathrm{Hz})$ & $\delta_{\mathrm{C}}$ & $\delta_{\mathrm{H}}(J$ in $\mathrm{Hz})$ & $\delta_{\mathrm{C}}$ & $\delta_{\mathrm{H}}(J$ in $\mathrm{Hz})$ & $\delta_{\mathrm{C}}$ & $\delta_{\mathrm{H}}(J$ in $\mathrm{Hz})$ \\
\hline 1 & 77.6 & $3.83 \mathrm{~d}(8.5)$ & 77.5 & $3.82 \mathrm{dd}(3.5,11.5)$ & 77.5 & $\begin{array}{l}3.80 \text { dd }(4.0, \\
11.5)\end{array}$ & 77.5 & $3.84 \mathrm{~m}$ & 77.4 & $3.83 \mathrm{~m}$ \\
\hline 2 & 43.0 & $2.23 \mathrm{~m}, 2.55 \mathrm{~m}$ & 43.1 & $\begin{array}{r}2.55 \mathrm{~m}, 2.23 \mathrm{ddd} \\
(12,11.5,11.5)\end{array}$ & 42.9 & $2.23 \mathrm{~m}, 2.51 \mathrm{~m}$ & 42.8 & $2.24 \mathrm{~m}, 2.53 \mathrm{~m}$ & 42.7 & $2.25 \mathrm{~m}, 2.55 \mathrm{~m}$ \\
\hline 3 & 67.4 & $3.89 \mathrm{~m}$ & 67.4 & $3.89 \mathrm{~m}$ & 67.3 & $3.83 \mathrm{~m}$ & 67.3 & $3.84 \mathrm{~m}$ & 67.4 & $3.89 \mathrm{~m}$ \\
\hline 4 & 43.5 & $2.70 \mathrm{~m}$ & 43.6 & $2.70 \mathrm{~m}$ & 43.6 & $2.75 \mathrm{~m}$ & 43.4 & $2.70 \mathrm{~m}$ & 43.5 & $2.72 \mathrm{~m}$ \\
\hline 5 & 142.9 & & 143.1 & & 143.7 & & 143.7 & & 143.0 & \\
\hline 6 & 127.8 & $6.04 \mathrm{~d}(5.0)$ & 128.0 & $6.06 \mathrm{~d}(5.0)$ & 126.5 & $5.94 \mathrm{~d}(5.0)$ & 126.5 & $5.95 \mathrm{~d}(5.0)$ & 127.7 & $6.07 \mathrm{~d}(5.0)$ \\
\hline 7 & 64.3 & $4.07 \mathrm{~s}$ & 64.7 & $4.09 \mathrm{bs}$ & 66.3 & $4.46 \mathrm{~s}$ & 66.2 & $4.51 \mathrm{~d}(12.0)$ & 64.7 & $4.14 \mathrm{bs}$ \\
\hline 8 & 38.7 & $1.77 \mathrm{~m}$ & 38.5 & $1.77 \mathrm{~m}$ & 39.4 & $2.02 \mathrm{~m}$ & 38.7 & $2.07 \mathrm{dd}(3.5,7.5)$ & 37.6 & $1.77 \mathrm{~m}$ \\
\hline 9 & 43.1 & $2.14 \mathrm{~m}$ & 43.6 & $2.70 \mathrm{~m}$ & 38.3 & $2.76 \mathrm{~m}$ & 38.7 & $\begin{array}{l}2.87 \text { ddd }(5.5 \\
12.5,13.0)\end{array}$ & 42.7 & $2.35 \mathrm{~m}$ \\
\hline 10 & 44.0 & & 44.1 & 44.1 & 44.2 & & 44.3 & & 44.2 & \\
\hline 11 & 24.0 & $\begin{array}{c}1.41 \mathrm{~m}, 2.97 \mathrm{dd} \\
(3.5,14.0)\end{array}$ & 23.9 & $1.83 \mathrm{~m}, 2.90 \mathrm{~m}$ & 23.1 & $1.93 \mathrm{~m}, 2.92 \mathrm{~m}$ & 33.6 & $2.14 \mathrm{~m}, 3.36 \mathrm{~m}$ & 34.1 & $2.10 \mathrm{~m}, 3.34 \mathrm{~m}$ \\
\hline 12 & 37.4 & $1.31 \mathrm{~m}, 1.88 \mathrm{~m}$ & 40.2 & $1.33 \mathrm{~m}, 1.77 \mathrm{~m}$ & 32.4 & $1.42 \mathrm{~m}, 2.51 \mathrm{~m}$ & 72.4 & $\begin{array}{l}4.96 \mathrm{dd}(5.0, \\
11.6)\end{array}$ & 79.2 & $3.80 \mathrm{~m}$ \\
\hline 13 & 45.2 & & 39.9 & & 44.5 & & 49.7 & & 45.5 & \\
\hline 14 & 48.3 & $2.11 \mathrm{~m}$ & 50.2 & $2.10 \mathrm{~m}$ & 87.5 & & 89.7 & & 49.0 & $2.17 \mathrm{~m}$ \\
\hline 15 & 36.8 & $2.69 \mathrm{~m}, 1.83 \mathrm{~m}$ & 32.1 & $1.61 \mathrm{~m}, 2.55 \mathrm{~m}$ & 40.8 & $2.04 \mathrm{~m}, 2.62 \mathrm{~m}$ & 41.2 & $2.20 \mathrm{~m}, 2.66 \mathrm{~m}$ & 31.9 & $1.81 \mathrm{~m}, 2.65 \mathrm{~m}$ \\
\hline 16 & 80.5 & $4.64 \mathrm{~m}$ & 81.5 & $\begin{array}{l}4.61 \text { ddd }(7.5,11.5 \text {, } \\
12.5)\end{array}$ & 82.2 & $\begin{array}{l}5.12 \text { ddd }(6.5 \\
7.0,7.5)\end{array}$ & 82.4 & $\begin{array}{l}5.22 \text { ddd }(6.0 \\
7.5,8.0)\end{array}$ & 81.5 & $\begin{array}{l}4.69 \text { ddd }(7.5 \\
\quad 8.0,8.5)\end{array}$ \\
\hline 17 & 56.6 & $1.82 \mathrm{~m}$ & 63.0 & $1.88 \mathrm{~m}$ & 59.5 & $2.80 \mathrm{~m}$ & 59.4 & $3.18 \mathrm{dd}(8.0,7.0)$ & 62.9 & $2.25 \mathrm{~m}$ \\
\hline 18 & 65.2 & $\begin{array}{l}3.41 \mathrm{~d}(11.8), 4.07 \\
\quad \mathrm{~d}(11.9)\end{array}$ & 16.4 & $0.98 \mathrm{~s}$ & 19.7 & $1.12 \mathrm{~s}$ & 13.5 & $1.37 \mathrm{~s}$ & 11.1 & $1.24 \mathrm{~s}$ \\
\hline 19 & 12.5 & $1.26 \mathrm{~s}$ & 12.7 & $1.34 \mathrm{~s}$ & 13.0 & $1.36 \mathrm{~s}$ & 13.0 & $1.38 \mathrm{~s}$ & 12.6 & $1.36 \mathrm{~s}$ \\
\hline 20 & 35.9 & $2.23 \mathrm{~m}$ & 41.7 & $1.99 \mathrm{dd}(6.5,7.0)$ & 41.7 & $2.10 \mathrm{~m}$ & 42.6 & $2.31 \mathrm{~m}$ & 43.0 & $2.25 \mathrm{~m}$ \\
\hline 21 & 14.5 & $0.85 \mathrm{~d}(6.5)$ & 14.8 & $1.04 \mathrm{~d}(7.0)$ & 15.1 & $1.09 \mathrm{~d}(7.0)$ & 14.4 & $1.41 \mathrm{~d}(6.0)$ & 14.1 & $1.36 \mathrm{~d}(6.0)$ \\
\hline 22 & 109.9 & & 109.2 & & 109.4 & & 109.8 & & 109.5 & \\
\hline 23 & 27.8 & $2.47 \mathrm{~m}, 2.61 \mathrm{~m}$ & 33.0 & $1.78 \mathrm{~m}$ & 33.1 & $1.82 \mathrm{~m}$ & 33.2 & $1.87 \mathrm{~m}$ & 31.9 & $1.79 \mathrm{~m}, 2.65 \mathrm{~m}$ \\
\hline 24 & 32.8 & $2.03 \mathrm{~m}, 2.23 \mathrm{~m}$ & 28.7 & $2.23 \mathrm{~m}, 2.70 \mathrm{~m}$ & 28.8 & $2.25 \mathrm{~m}, 2.74 \mathrm{~m}$ & 28.9 & $2.25 \mathrm{~m}, 2.77 \mathrm{~m}$ & 29.8 & $2.24 \mathrm{~m}, 2.73 \mathrm{~m}$ \\
\hline 25 & 151.1 & & 144.3 & & 144.3 & & 144.4 & & 144.3 & \\
\hline 26 & 65.2 & $4.43 \mathrm{~s}$ & 64.3 & $\begin{array}{l}4.00 \mathrm{~d}(12.0), 4.40 \mathrm{~d} \\
\quad(12.0)\end{array}$ & 64.7 & $\begin{array}{l}4.00 \mathrm{~d}(9.5), 4.47 \\
\quad \mathrm{~d}(11.5)\end{array}$ & 64.7 & $\begin{array}{l}4.05 \mathrm{~d}(12.0) \\
\quad 4.51 \mathrm{~d}(12.0)\end{array}$ & 64.3 & $\begin{array}{l}4.00 \mathrm{~d}(12.0), \\
\quad 4.44 \mathrm{~d}(12.0)\end{array}$ \\
\hline 27 & 107.8 & $5.04 \mathrm{~s}, 5.38 \mathrm{~s}$ & 108.4 & $4.78 \mathrm{~d}(9.5)$ & 108.5 & $4.87 \mathrm{~d}(9.5)$ & 108.5 & $4.78 \mathrm{~s}, 4.81 \mathrm{~s}$ & 180.4 & $4.79 \mathrm{~s}, 4.77 \mathrm{~s}$ \\
\hline
\end{tabular}

on their ${ }^{2} J_{\mathrm{H}-\mathrm{C}}$ and ${ }^{3} J_{\mathrm{H}-\mathrm{C}}$ correlations with C-22 $\left(\delta_{\mathrm{C}} 212.9\right)$, respectively. The long-range correlations of the terminal hydroxymethyl signal at $\delta_{\mathrm{H}} 4.39(\mathrm{~s})$ with the carbon resonances at $\delta_{\mathrm{C}} 150.1(\mathrm{C}-25), 108.3(\mathrm{C}-27)$, and 27.0 (C-24), and C-24, $\mathrm{C}-25$ and $\mathrm{C}-26$ to $\mathrm{H}_{2}-27$ ( $\delta_{\mathrm{H}} 5.07$ and 5.42 , both s), were of assistance to deduce the remaining part of the side chain as shown in Figure 3. The relative configuration was established via the 2D-ROESY data. The correlation of $\mathrm{H}-7$ with $\alpha$-oriented $\mathrm{H}-9\left(\delta_{\mathrm{H}} 2.55\right.$, ddd, $\left.J=5.0,5.0,11.5 \mathrm{~Hz}\right)$ and the cross-peak between these two resonances and exchangeable proton signal at $\delta_{\mathrm{H}} 6.48[\mathrm{C}-14(\mathrm{OH})]$ confirmed the orientation of the $\mathrm{OH}$ groups as $7 \beta$ and $14 \alpha$. Thus, the structure of metabolite 2 was defined as cholesta-5,25(27)-diene-1 $\beta, 3 \beta, 7 \beta, 14 \alpha, 26$-pentaol16,22-dione.

The molecular formula of metabolite 3 was established as $\mathrm{C}_{27} \mathrm{H}_{40} \mathrm{O}_{7}$ based on ${ }^{13} \mathrm{C}$ NMR and HRMS data (obsd $[\mathrm{M}+$ $\mathrm{Na}]^{+}, m / z$ 499.2656; calcd 499.2672). While the carbon resonances are similar, the ${ }^{1} \mathrm{H}$ NMR spectrum of 3 showed two discrepancies in comparison to 2 . When the spin-system starting from the distinguishing olefinic resonance H-6 was established, the upfield shift of the oxymethine proton $\mathrm{H}-7$ was significant, suggesting a configurational difference in metabolite $3\left(\delta_{\mathrm{H}} 4.96\right.$ in $2, \delta_{\mathrm{H}} 4.32$ in 3$)$. As a result of this configurational change, the $\mathrm{H}_{2}-15$ resonances were also affected $\left(\delta_{\mathrm{H}} 3.20\right.$ and 3.05 in $2, \delta_{\mathrm{H}} 2.64$ and 2.49 in 3 ), signifying an intramolecular hydrogen bond between the C-14 and C-7 hydroxy groups. The orientational difference of $\mathrm{C}-7(\mathrm{OH})$ was further supported by the ROESY spectrum. The cross-peak from $\beta$-oriented $\mathrm{H}-8$ $\left(\delta_{\mathrm{H}} 1.95\right)$ to $\mathrm{H}-7\left(\delta_{\mathrm{H}} 4.32\right)$ and from $\alpha$-oriented H-9 $\left(\delta_{\mathrm{H}} 2.77\right)$ to the exchangeable proton of $\mathrm{C}-14(\mathrm{OH})\left(\delta_{\mathrm{H}} 6.48\right)$ confirmed $\alpha$ cofacial orientations of $\mathrm{C}-7(\mathrm{OH})$ and $\mathrm{C}-14(\mathrm{OH})$. On the basis of these findings, the structure of compound 3 was defined as cholesta-5,25(27)-diene-1 $\beta, 3 \beta, 7 \alpha, 14 \alpha, 26$-pentaol16,22-dione.

The HRMS spectrum of metabolite 4 showed a major ion peak at $m / z 497.2532$ (calcd for $\mathrm{C}_{27} \mathrm{H}_{38} \mathrm{O}_{7} \mathrm{Na}$ 497.2512), indicating a molecular formula of $\mathrm{C}_{27} \mathrm{H}_{38} \mathrm{O}_{7}$ with nine indices of hydrogen deficiency. The ${ }^{1} \mathrm{H}$ and ${ }^{13} \mathrm{C}$ NMR spectra of 4 were similar to those of $\mathbf{2}$ and 3, except the signals deriving from an additional carbonyl resonance $\left(\delta_{\mathrm{C}} 200.1\right)$ and those in its close proximity. Examination of the $1 \mathrm{D}$ and $2 \mathrm{D}$ NMR spectra of 4 permitted establishment of the additional carbonyl group at C7. The correlation of $\mathrm{H}-15_{\alpha}$, which was deduced by the crosspeak from $\mathrm{H}-15_{\mathrm{ax}}$ to $\mathrm{Me}-18 \beta$, and exchangeable proton of C$14(\mathrm{OH})\left(\delta_{\mathrm{H}} 6.39\right)$ in the ROESY spectrum revealed the orientation of the hydroxy group at $\mathrm{C}-14$ to be $\alpha$. Consequently, the structure of metabolite 4 was defined as cholesta-5,25(27)-diene-1 $\beta, 3 \beta, 14 \alpha, 26$-tetraol-7,16,22-trione.

The molecular formula of 5 was determined as $\mathrm{C}_{29} \mathrm{H}_{40} \mathrm{O}_{8}$ based on the major ion peak at $m / z 555.2377[\mathrm{M}+\mathrm{K}]^{+}($calcd 
Table 3. ${ }^{1} \mathrm{H}$ and ${ }^{13} \mathrm{C}$ NMR Data of Compounds $12-15$ (500 MHz, Pyridine- $d_{5}$ )

\begin{tabular}{|c|c|c|c|c|c|c|c|c|}
\hline \multirow[b]{2}{*}{ position } & \multicolumn{2}{|r|}{12} & \multicolumn{2}{|r|}{13} & \multicolumn{2}{|r|}{14} & \multicolumn{2}{|r|}{15} \\
\hline & $\delta_{\mathrm{C}}$ & $\delta_{\mathrm{H}}(J$ in $\mathrm{Hz})$ & $\delta_{\mathrm{C}}$ & $\delta_{\mathrm{H}}(J$ in $\mathrm{Hz})$ & $\delta_{\mathrm{C}}$ & $\delta_{\mathrm{H}}(J$ in $\mathrm{Hz})$ & $\delta_{\mathrm{C}}$ & $\delta_{\mathrm{H}}(J$ in $\mathrm{Hz})$ \\
\hline 1 & 75.3 & $3.93 \mathrm{~m}$ & 78.3 & $3.82 \mathrm{~d}(10.5)$ & 76.2 & $3.84 \mathrm{~m}$ & 77.5 & $4.30 \mathrm{~m}$ \\
\hline 2 & 41.7 & $2.23 \mathrm{~m}, 2.70 \mathrm{~m}$ & 42.4 & $2.35 \mathrm{~m}, 2.57 \mathrm{~m}$ & 43.2 & $2.25 \mathrm{~m}, 2.60 \mathrm{~m}$ & 41.4 & $2.31 \mathrm{~m}, 2.58 \mathrm{~m}$ \\
\hline 3 & 67.4 & $3.88 \mathrm{~m}$ & 67.0 & $3.91 \mathrm{~m}$ & 65.9 & $3.90 \mathrm{~m}$ & 65.2 & $4.17 \mathrm{~m}$ \\
\hline 4 & 43.9 & $2.70 \mathrm{~m}$ & 43.6 & $2.70 \mathrm{~m}, 2.80 \mathrm{~m}$ & 43.6 & $2.75 \mathrm{~m}$ & 43.4 & $2.77 \mathrm{~m}$ \\
\hline 5 & 143.2 & & 164.7 & & 165.3 & & 63.4 & \\
\hline 6 & 128.7 & $6.07 \mathrm{~d}(5.5)$ & 126.2 & $6.12 \mathrm{~s}$ & 128.4 & $6.02 \mathrm{~s}$ & 64.8 & $3.41 \mathrm{~d}(3.2)$ \\
\hline 7 & 64.3 & $4.11 \mathrm{bs}$ & 200.8 & & 200.9 & & 68.1 & $4.75 \mathrm{~m}$ \\
\hline 8 & 38.6 & $1.77 \mathrm{~m}$ & 79.0 & & 49.5 & $2.94 \mathrm{~m}$ & 36.6 & $2.47 \mathrm{~m}$ \\
\hline 9 & 49.3 & $2.32 \mathrm{dd}(10.0,10.5)$ & 47.1 & $3.18 \mathrm{~d}(3.5)$ & 45.3 & $2.84 \mathrm{~m}$ & 36.3 & $2.88 \mathrm{~m}$ \\
\hline 10 & 46.4 & & 45.7 & & 44.9 & & 40.8 & \\
\hline 11 & 66.2 & $4.38 \mathrm{~d}(12.5)$ & 21.0 & $\begin{array}{l}2.47 \text { ddd }(13.5,13.0,12.5) \\
\quad 3.25 \mathrm{~d}(13.0)\end{array}$ & 23.2 & $1.99 \mathrm{~d}(12.5), 2.88 \mathrm{~m}$ & 24.5 & $1.76 \mathrm{~m}, 2.57 \mathrm{~m}$ \\
\hline 12 & 49.7 & $\begin{array}{l}1.70 \mathrm{t}(11.5) \\
2.51 \mathrm{~m}\end{array}$ & 33.7 & 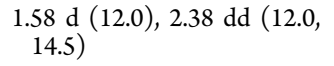 & 31.9 & $1.44 \mathrm{~m}, 2.33 \mathrm{~m}$ & 32.7 & $1.36 \mathrm{~m}, 2.33 \mathrm{~m}$ \\
\hline 13 & 40.1 & & 45.6 & & 45.4 & & 44.7 & \\
\hline 14 & 48.6 & $1.92 \mathrm{~m}$ & 86.5 & & 84.5 & & 88.3 & \\
\hline 15 & 31.8 & $1.57 \mathrm{~m}, 2.51 \mathrm{~m}$ & 37.6 & $\begin{array}{l}2.71 \mathrm{~m}, 3.42 \text { ddd }(7.0,7.5 \text {, } \\
7.5)\end{array}$ & 41.9 & $\begin{array}{l}2.24 \text { ddd }(11.5,12.0,12.5), 3.53 \text { ddd } \\
\quad(7.5,7.5,5.5)\end{array}$ & 40.5 & $1.92 \mathrm{~m}, 2.45 \mathrm{~m}$ \\
\hline 16 & 81.6 & $\begin{array}{l}4.58 \text { ddd }(7.5,7.5 \\
7.0)\end{array}$ & 82.2 & $5.14 \mathrm{~m}$ & 82.3 & $5.08 \mathrm{~m}$ & 82.1 & $5.06 \mathrm{~m}$ \\
\hline 17 & 62.3 & $1.93 \mathrm{dd}(7.5,8.0)$ & 58.8 & $2.82 \mathrm{~m}$ & 58.2 & $2.71 \mathrm{~m}$ & 59.1 & $2.69 \mathrm{~m}$ \\
\hline 18 & 16.8 & $0.95 \mathrm{~s}$ & 21.0 & $1.74 \mathrm{~s}$ & 20.3 & $1.13 \mathrm{~s}$ & 20.0 & $1.04 \mathrm{~s}$ \\
\hline 19 & 12.3 & $1.41 \mathrm{~s}$ & 14.3 & $1.90 \mathrm{~s}$ & 12.1 & $1.46 \mathrm{~s}$ & 11.1 & $1.55 \mathrm{~s}$ \\
\hline 20 & 41.7 & $1.97 \mathrm{dd}(7.5,7.5)$ & 40.6 & $2.17 \mathrm{~m}$ & 41.7 & $2.23 \mathrm{~m}$ & 41.5 & $2.04 \mathrm{dd}(7.0,8.0)$ \\
\hline 21 & 14.7 & $1.01 \mathrm{~d}(6.5)$ & 15.2 & $1.12 \mathrm{~d}(7.0)$ & 15.2 & $1.11 \mathrm{~d}(7.0)$ & 20.5 & $1.05 \mathrm{~d}(9.0)$ \\
\hline 22 & 109.3 & & 109.6 & & 109.6 & & 109.5 & \\
\hline 23 & 32.9 & $1.76 \mathrm{~m}$ & 33.1 & $1.76 \mathrm{~m}, 1.80 \mathrm{~m}$ & 33.1 & $1.79 \mathrm{~m}$ & 33.1 & $1.78 \mathrm{~m}$ \\
\hline 24 & 28.8 & $2.23 \mathrm{~m}, 2.70 \mathrm{~m}$ & 28.7 & $2.15 \mathrm{~m}, 2.60 \mathrm{~m}$ & 29.5 & $2.21 \mathrm{~m}, 2.70 \mathrm{~m}$ & 28.8 & $2.25 \mathrm{~m}, 2.70 \mathrm{~m}$ \\
\hline 25 & 144.7 & & 144.3 & & 144.5 & & 144.3 & \\
\hline 26 & 64.9 & $\begin{array}{l}3.98 \mathrm{~d}(12.5), 4.38 \mathrm{~d} \\
\quad(12.5)\end{array}$ & 64.6 & $3.96 \mathrm{~d}(12.5), 4.40 \mathrm{~d}(12.0)$ & 64.7 & $4.41 \mathrm{~d}(12.0), 3.95 \mathrm{~d}(12.0)$ & 64.7 & $\begin{array}{l}4.43 \mathrm{~d}(12.0), 3.99 \mathrm{~d} \\
\quad(12.0)\end{array}$ \\
\hline 27 & 109.3 & $4.79 \mathrm{~s}, 4.77 \mathrm{~s}$ & 108.4 & $4.71 \mathrm{~s}, 4.74 \mathrm{~s}$ & 108.4 & $4.75 \mathrm{~d}(8.5)$ & 108.5 & $4.77 \mathrm{~d}(10.0)$ \\
\hline
\end{tabular}
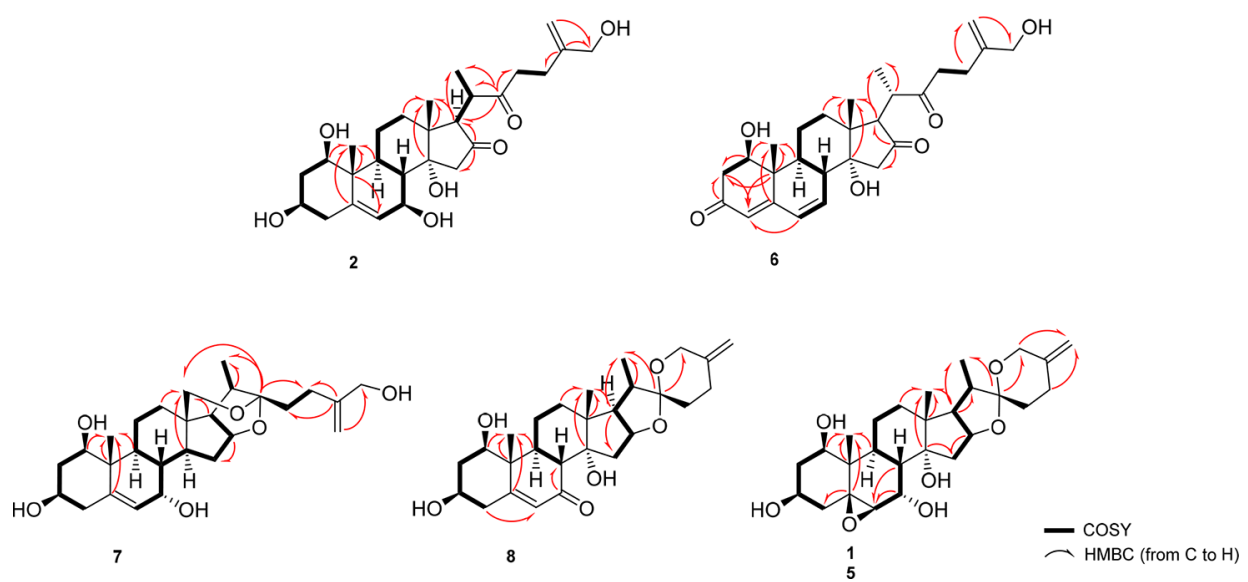

Figure 3. HMBC and COSY correlations of 2, 6, 7, 8, and 15.

555.2360 for $\left.\mathrm{C}_{29} \mathrm{H}_{40} \mathrm{O}_{8} \mathrm{~K}\right)$ in the HRMS spectrum. In the ${ }^{1} \mathrm{H}$ and ${ }^{13} \mathrm{C}$ NMR spectra of 5 , the resonances were almost superimposable with those of compound 4, except additional signals originating from an acetyl group $\left[\delta_{\mathrm{H}} 2.00\right.$, s; $\delta_{\mathrm{C}} 20.5$ (q) and $170.4(\mathrm{~s})]$. In the ${ }^{1} \mathrm{H}$ NMR spectrum, the downfield shift for $\mathrm{H}_{2}-26$ (ca. $0.30 \mathrm{ppm}$ at $\delta_{\mathrm{H}} 4.69$ ) and an upfield shift for $\mathrm{H}_{2}$ 27 (ca. $0.30 \mathrm{ppm}$ at $\delta_{\mathrm{H}} 5.13$ ) implied the acylation position as $\mathrm{C}-26(O)$. This assumption was substantiated by the long-range $\mathrm{HMBC}$ correlation from the ester carbonyl signal at $\delta_{\mathrm{C}} 170.4$ to $\mathrm{H}_{2}$-26a $\left(\delta_{\mathrm{H}} 4.69\right)$. Based on the NOE correlations from $\mathrm{H}-9$ and $\mathrm{H}-17\left(\delta_{\mathrm{H}} 2.94\right.$ and 3.87 , respectively) to the exchangeable proton, the orientation of $\mathrm{C}-14(\mathrm{OH})\left(\delta_{\mathrm{H}} 6.41\right)$ was determined to be $\alpha$. Thus, the structure of 5 was elucidated as $26-O$ acetylcholesta-5,25(27)-diene-1 $\beta, 3 \beta, 14 \alpha, 26$-tetraol-7,16,22-trione.

The HRESIMS spectrum of 6 , exhibited a sodium adduct ion at $m / z 479.2403[\mathrm{M}+\mathrm{Na}]^{+}($calcd 479.2410) and led to establishment of its molecular formula as $\mathrm{C}_{27} \mathrm{H}_{36} \mathrm{O}_{6}$ with 10 indices of hydrogen deficiency. In the ${ }^{1} \mathrm{H}$ and ${ }^{13} \mathrm{C}$ NMR spectra of 6 , the signals arising from the rings $\mathrm{C}$ and $\mathrm{D}$ and the side 
chain were similar to those of compounds $\mathbf{2 - 5}$, accounting for five indices of hydrogen deficiency. Inspection of the $1 \mathrm{D}$ and 2D NMR spectra revealed an additional carbonyl group $\left(\delta_{\mathrm{C}}\right.$ $197.7)$ together with a trisubstituted $\left(\delta_{\mathrm{C}} 124.3,162.7\right.$, and $\delta_{\mathrm{H}}$ $5.93)$ and a disubstituted $\left(\delta_{\mathrm{C}} 130.1,140.1 ; \delta_{\mathrm{H}}, 6.30,6.25\right.$, respectively) double-bond system. The oxymethine resonance at $\delta_{\mathrm{C}} 72.5$ was readily assigned to $\mathrm{C}-1$ based on its long-range correlation with $\mathrm{H}_{3}-19\left(\delta_{\mathrm{H}} 1.40\right)$. In the COSY spectrum, the $\mathrm{H}-1 \quad\left(\delta_{\mathrm{H}} 4.27\right)$ resonance was correlating with a methylene group $\left(\delta_{\mathrm{H}} 2.99\right.$ and $\left.3.05, \mathrm{H}_{2}-2\right)$, which in turn had no further cross-peaks. In the $\mathrm{HMBC}$ spectrum, the ${ }^{2} J_{\mathrm{C}-\mathrm{H}}$ correlation between the carbonyl signal at $197.7 \mathrm{ppm}(\mathrm{C}-3)$ and $\delta_{\mathrm{H}} 2.99 /$ $3.05\left(\mathrm{H}_{2}-2\right)$ protons verified an oxidation at $\mathrm{C}-3$ to give a 3carbonyl group in 6 . The trisubstituted olefinic system was located at C-4(5) ( $\delta_{\mathrm{C}} 124.3$ and 162.7 , respectively) on the basis of the deshielding of C-5 due to the $\alpha, \beta$-unsaturated carbonyl functionality and key HMBCs from C-2 $\left(\delta_{\mathrm{C}} 44.9\right)$ and C-10 $\left(\delta_{\mathrm{C}} 42.4\right)$ to $\mathrm{H}-4\left(\delta_{\mathrm{H}} 5.93\right)$ and from C-5 $\left(\delta_{\mathrm{C}} 162.8\right)$ to $\mathrm{H}_{3}-19\left(\delta_{\mathrm{H}} 1.40\right)$. Thus, the disubstituted double-bond resonances $\left(\delta_{\mathrm{H}} 6.25, \mathrm{dd}, J=9.5,1.0 \mathrm{~Hz} ; \delta_{\mathrm{H}} 6.31\right.$, dd, $J=9.5$, $2.0 \mathrm{~Hz} ; \delta_{\mathrm{C}} 130.1$ and 140.1 , respectively) were directly assigned to $\mathrm{C}(\mathrm{H})-6$ and $\mathrm{C}(\mathrm{H})-7$ (Figure 3 ). Consequently, the structure of 6 was determined as cholesta-4,6,25(27)-triene- $1 \beta, 14 \alpha, 26$ triol-3,16,22-trione.

The HRMS spectrum of metabolite 7 provided a sodiated ion peak at $m / z$ 483.2784 $[\mathrm{M}+\mathrm{Na}]^{+}$(calcd 483.2723 for $\mathrm{C}_{27} \mathrm{H}_{40} \mathrm{O}_{6} \mathrm{Na}$ ), indicating eight indices of hydrogen deficiency and a 32 amu increase over 1 . In the ${ }^{1} \mathrm{H}$ NMR spectrum of 7 , the resonance of one of the tertiary methyl groups was absent, and an isolated oxymethylene group was evident from the ${ }^{1} \mathrm{H}$ and ${ }^{13} \mathrm{C}$ NMR and HSQC spectra as an $\mathrm{AB}$ system $\left(\delta_{\mathrm{H}} 4.07, \mathrm{~d}\right.$, $\left.J=11.9 \mathrm{~Hz} ; \delta_{\mathrm{H}} 3.41, \mathrm{~d}, J=11.8 \mathrm{~Hz} ; \delta_{\mathrm{C}} 65.2, \mathrm{t}\right)$. Examination of the COSY and TOCSY spectrum starting from the characteristic resonances, namely, oxymethine proton $\mathrm{H}-1$ and olefinic $\mathrm{H}-6$, permitted the location of the two major spin systems in the steroid framework (Figure 3 ) and revealed an oxygenation at C-7 $\left(\delta_{\mathrm{C}} 64.3 ; \delta_{\mathrm{H}} 4.07\right)$ as in metabolites 2 and 3. Furthermore, the new oxymethylene group was attributed to $\mathrm{CH}_{2}-18$ based on the key HMBCs from C-17 and C-14 to $\mathrm{H}_{2}$ 18 ( $\delta 4.07$ and 3.41). Interestingly, in the COSY spectrum, $\mathrm{H}$ 17 did not couple with $\mathrm{H}-20$, which in turn correlated with $\mathrm{CH}_{3}-21$, suggesting a ca. $90^{\circ}$ dihedral angle between $\mathrm{H}-17$ and $\mathrm{H}-20$. In addition, the third spin system was tracked from the characteristic $\mathrm{H}_{2}-27$ signals $\left(\delta_{\mathrm{H}} 5.04\right.$ and 5.38) through allylic couplings to the hydroxymethyl $\mathrm{H}_{2}-26\left(\delta_{\mathrm{H}} 4.43,2 \mathrm{H}\right)$ and $\mathrm{H}_{2}-$ $24\left(\delta_{\mathrm{H}} 2.03\right.$ and 2.23); the latter in turn coupled with $\mathrm{H}_{2}-23$ $\left(\delta_{\mathrm{H}} 2.47\right.$ and 2.61). The diastereotopic nature of $\mathrm{H}_{2}-26$, resonating as a $2 \mathrm{H}$ broad singlet, and carbon chemical shifts of C-25 $\left(\delta_{\mathrm{C}} 151.1\right)$ and C-27 $\left(\delta_{\mathrm{C}} 107.8\right)$ demonstrated cleavage of the C-22/C-26 oxygen bridge to afford an acyclic side chain. The carbon resonance observed at $\delta_{\mathrm{C}} 109.9$ was assigned to C22 based on the ${ }^{3} J_{\mathrm{C}-\mathrm{H}}$ correlations from this carbon to $\mathrm{H}-16$, $\mathrm{H}-17, \mathrm{H}_{3}-21$, and $\mathrm{H}_{2}-24$ in the HMBC spectrum. The correlation between $\mathrm{H}-16$ and $\mathrm{C}-22$ verified the oxygen bridge (Figure 3), suggesting a furostanol-type framework for metabolite 7. While all of the structural components accounted for seven out of eight indices of hydrogen deficiency, the absence of an additional multiple bond in the structure implied a recyclization. This assumption was substantiated by the longrange $\mathrm{HMBC}$ correlation between one of the $\mathrm{H}_{2}-18$ protons $\left(\delta_{\mathrm{H}} 4.07\right)$ and C-22 ( $\left.\delta_{\mathrm{C}} 109.9\right)$, revealing epoxy bridge formation and thus the acetal character of C-22. This sixmembered ring system, which forced the H-16/C-16/C-20/H-
20 system to adopt a dihedral angle of $82^{\circ}$ [see MM2minimized energy conformer of 7 (Figure 4)], also explained

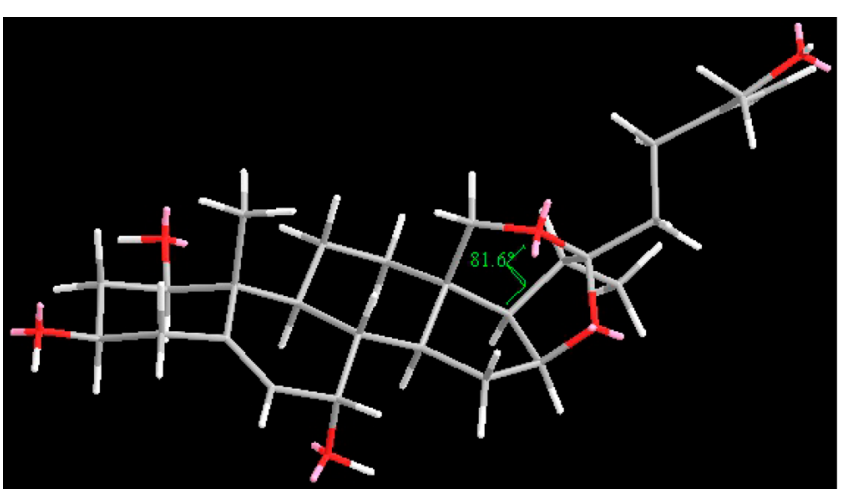

Figure 4. MM2 energy minimized conformer of 7.

the absence of coupling between $\mathrm{H}-17$ and $\mathrm{H}-21$. The $\alpha$ orientation of the hydroxy group at C-7 was deduced via the correlation of $\beta$-oriented H-8 $\left(\delta_{\mathrm{H}} 1.77\right)$ and $\mathrm{H}-7\left(\delta_{\mathrm{H}} 4.07\right)$ in the NOESY spectrum. Thus, the structure of metabolite 7 was established as 18(22)-epoxyfurosta-5,25(27)-diene$1 \beta, 3 \beta, 7 \alpha, 26$-tetraol.

The HRMS data of metabolite $\mathbf{8}$ exhibited a protonated molecular ion at $m / z 445.2956[\mathrm{M}+\mathrm{H}]^{+}\left(\right.$calcd for $\mathrm{C}_{27} \mathrm{H}_{41} \mathrm{O}_{5}$ 445.2954), revealing a $16 \mathrm{amu}$ increase over $\mathrm{NR}(1)$. In the low-field region of the ${ }^{1} \mathrm{H}$ NMR spectrum, an additional lowfield proton at $\delta_{\mathrm{H}} 4.09$ was observed. Furthermore, deshielding of the characteristic olefinic resonance of H-6 $\left(\delta_{\mathrm{H}} 6.06, \mathrm{~d}, J=\right.$ $5.0 \mathrm{~Hz}$ ) inferred an adjacent oxygenation. The significant COSY correlation between the resonance at $\delta_{\mathrm{H}} 4.09(\mathrm{H}-7)$ and $\mathrm{H}-6\left(\delta_{\mathrm{H}} 6.06\right)$ implied the position of functionalization as C-7 (Figure 3$)$. The long-range correlations of C-5 $\left(\delta_{\mathrm{C}} 143.1\right)$ and C-6 $\left(\delta_{\mathrm{C}} 128.0\right)$ with this oxymethine proton also substantiated the proposed modification. The $\alpha$-orientation of $\mathrm{C}-7(\mathrm{OH})$ was established via the ROESY cross-peak between $\mathrm{H}-8\left(\delta_{\mathrm{H}} 1.77\right)$ and $\mathrm{H}-7$. Based on these findings, the structure of $\mathbf{8}$ was determined as spirost-5,25(27)-diene- $1 \beta, 3 \beta, 7 \beta$-triol.

In the HRMS spectrum of 9, a sodium adduct ion was observed at $m / z 483.2733[\mathrm{M}+\mathrm{Na}]^{+}$(calcd for $\mathrm{C}_{27} \mathrm{H}_{40} \mathrm{O}_{6} \mathrm{Na}$ 483.2723), signifying the presence of two hydroxy groups due to the $32 \mathrm{amu}$ increase compared to 1 . Inspection of the ${ }^{1} \mathrm{H}$ NMR spectrum of 9 revealed an additional low-field signal at $\delta_{\mathrm{H}} 4.46$, whereas a new oxymethine carbon resonance at $\delta_{\mathrm{C}}$ 66.3 was noted in the ${ }^{13} \mathrm{C}$ NMR and DEPT135 spectra together with an oxygenated tertiary carbon at $\delta_{\mathrm{C}} 87.5$. The correlation between $\mathrm{H}-6\left(\delta_{\mathrm{H}} 5.94, \mathrm{~d}, J=5.0 \mathrm{~Hz}\right)$ and the new signal resonating at $\delta_{\mathrm{H}} 4.46$ verified the first oxygenation at C-7, as in compound 8. The long-distance correlations between the tertiary carbon at $\delta_{\mathrm{C}} 87.5$ and $\mathrm{H}_{3}-18\left(\delta_{\mathrm{H}} 1.12\right), \mathrm{H}-8\left(\delta_{\mathrm{H}} 2.02\right)$, and $\mathrm{H}_{2}-15 \mathrm{a}\left(\delta_{\mathrm{H}} 2.62\right)$ in the HMBC spectrum verified an oxygenation at C-14. In the ROESY spectrum, correlation of $\mathrm{H}$ $7\left(\delta_{\mathrm{H}} 4.46\right)$ with $\beta$-oriented H-8 $\left(\delta_{\mathrm{H}} 2.02\right)$ and a cross-peak between the exchangeable proton signal of $14-\mathrm{OH}$ at $\delta_{\mathrm{H}} 6.18$ and $\mathrm{H}-17 \alpha\left(\delta_{\mathrm{H}} 2.80\right)$ revealed the $\alpha$-orientations of the hydroxy groups. Consequently, the structure of metabolite 9 was defined as spirosta-5,25(27)-diene-1 $\beta, 3 \beta, 7 \alpha, 14 \alpha$-tetraol.

The molecular formula of 10 was determined to be $\mathrm{C}_{27} \mathrm{H}_{40} \mathrm{O}_{7}$ based on the protonated molecular ion at $\mathrm{m} / z$ 477.2848 [M + $\mathrm{H}]^{+}$(calcd for $\mathrm{C}_{27} \mathrm{H}_{41} \mathrm{O}_{7} 477.2858$ ), and the $48 \mathrm{amu}$ difference in comparison to $\mathbf{1}$ suggested a trihydroxy analogue. Examination of the $1 \mathrm{D}$ and $2 \mathrm{D}$ NMR spectra revealed that 
the first two oxygenation positions were C-7 and C-14 as in 9. The remaining oxymethine resonance at $\delta_{\mathrm{C}} 72.4$ displayed a strong ${ }^{3} J_{\mathrm{C}-\mathrm{H}}$ correlation with the methyl signal of $\mathrm{H}_{3}-18\left(\delta_{\mathrm{H}}\right.$ $1.37)$, substantiating the other oxygenation position at $\mathrm{C}-12$. From the ROESY spectrum, the $\alpha$-oriented hydroxy group at C-7 was readily deduced via the correlation of $\beta$-oriented $\mathrm{H}-8$ $\left(\delta_{\mathrm{H}} 2.07\right)$ and $\mathrm{H}-7\left(\delta_{\mathrm{H}} 4.52\right)$, whereas $\mathrm{C}-12(\mathrm{OH})$ was assigned a $\beta$-orientation due to the cross-peak between $\mathrm{H}-17 \alpha\left(\delta_{\mathrm{H}} 3.18\right)$ and $\mathrm{H}-12\left(\delta_{\mathrm{H}} 4.96\right)$. Furthermore, the orientation of C$14(\mathrm{OH})$ was inferred from the correlation of the exchangeable proton $\left(\delta_{\mathrm{H}} 6.16\right)$ with $\mathrm{H}-15 \mathrm{a}\left(\delta_{\mathrm{H}} 2.66\right)$, which in turn had a correlation with $\mathrm{H}-16 \alpha\left(\delta_{\mathrm{H}} 5.22\right.$, ddd, $\left.J=7.5,7.5,6.0 \mathrm{~Hz}\right)$. Consequently, the structure of $\mathbf{1 0}$ was elucidated as spirost5,25(27)-diene-1 $\beta, 3 \beta, 7 \alpha, 12 \beta, 14 \alpha$-pentaol.

The HRMS spectrum of metabolite $\mathbf{1 1}$ provided a protonated molecular ion at $m / z 461.2904[\mathrm{M}+\mathrm{H}]^{+}$(calcd for $\mathrm{C}_{27} \mathrm{H}_{41} \mathrm{O}_{6} 461.2903$ ), indicating a $32 \mathrm{amu}$ increase over NR (1). Two additional low-field oxymethine resonances at $\delta_{\mathrm{C}} 79.2$ and 64.7 deduced from the ${ }^{13} \mathrm{C}$ NMR and DEPT135 spectra suggested two sites of oxygenation. The first location was evident from the COSY correlation from the olefinic H-6 $\left(\delta_{\mathrm{H}}\right.$ $6.07)$ to $\mathrm{H}-7\left(\delta_{\mathrm{H}} 4.14\right)$, whereas the key long-range correlation between the new oxymethine carbon resonance at $\delta_{\mathrm{C}} 79.2$ and characteristic $\mathrm{H}_{3}-18\left(\delta_{\mathrm{H}} 1.24\right)$ together with the spin system tracked from H-6 to H-12 justified the position of the second hydroxy group at C-12 as in 10. The ROESY correlation of $\mathrm{H}$ 12 with $\mathrm{H}-17 \alpha\left(\delta_{\mathrm{H}} 2.25\right)$ and a cross-peak between $\mathrm{H}-7\left(\delta_{\mathrm{H}}\right.$ 4.14) and $\mathrm{H}-8 \beta\left(\delta_{\mathrm{H}} 1.77\right)$ revealed the orientations of the $\mathrm{OH}$ groups as $\beta$ and $\alpha$, respectively. Thus, the structure of metabolite 11 was elucidated as spirosta-5,25(27)diene$1 \beta, 3 \beta, 7 \alpha, 12 \beta$-tetraol.

The HRMS data of metabolite $\mathbf{1 2}$ exhibited a protonated molecular ion at $m / z[\mathrm{M}+\mathrm{H}]^{+} 461.2901$ (calcd for $\mathrm{C}_{27} \mathrm{H}_{41} \mathrm{O}_{6}$ 461.2903), revealing a $32 \mathrm{amu}$ increase over 1 . Together with the characteristic signals of NR (1) an additional low-field resonance at $\delta_{\mathrm{H}} 4.11$ was observed in the ${ }^{1} \mathrm{H}$ NMR spectrum, whereas ${ }^{13} \mathrm{C}$ NMR and DEPT135 spectra revealed two additional oxymethine signals, suggesting a dihydroxy analogue of 1 . From the characteristic methyl doublet $\left(\mathrm{H}_{3}-21: \delta_{\mathrm{H}} 1.01, \mathrm{~d}\right.$, $J=6.5 \mathrm{~Hz})$ and $\mathrm{H}-6$ olefinic resonance $\left(\delta_{\mathrm{H}} 6.07, \mathrm{~d}, J=5.5\right)$ (Table 3 ), the spin system and its corresponding carbons constituting the $\mathrm{B}, \mathrm{C}, \mathrm{D}$, and $\mathrm{E}$ rings were deduced using the COSY, TOCSY, and HSQC spectra and revealed oxygenation sites as C-7 and C-11. The key HMBCs from C-11 $\left(\delta_{\mathrm{C}} 66.2\right)$ to $\mathrm{H}-12 \mathrm{a}\left(\delta_{\mathrm{H}} 2.51\right)$ and $\mathrm{H}-9\left(\delta_{\mathrm{H}} 2.32, \mathrm{dd}, J=10.0,10.5\right)$ and from C-6 $\left(\delta_{\mathrm{C}} 128.7\right)$ and C-8 $\left(\delta_{\mathrm{C}} 38.6\right)$ to H-7 $\left(\delta_{\mathrm{H}} 4.11\right)$ also supported these findings. Observation of the cross-peaks between $\mathrm{H}-11\left(\delta_{\mathrm{H}} 4.38, \mathrm{~d}, J=12.5 \mathrm{~Hz}\right)$ and $\mathrm{H}_{3}-18 \beta\left(\delta_{\mathrm{H}}\right.$ $0.95)$ and $\mathrm{H}_{3}-19\left(\delta_{\mathrm{H}} 1.41\right)$ and between $\mathrm{H}-7\left(\delta_{\mathrm{H}} 4.11\right)$ to $\mathrm{H}-8$ $\left(\delta_{\mathrm{H}} 1.77\right)$ substantiated $\alpha$-cofacial orientations of both HO-11 and HO-12. Based on these findings, the structure of $\mathbf{1 2}$ was defined as spirosta-5,25(27)-diene-1 $\beta, 3 \beta, 7 \alpha, 11 \alpha$-tetraol.

The HRMS spectrum of metabolite 13 provided a protonated molecular ion at $m / z$ 475.2704 $[\mathrm{M}+\mathrm{H}]^{+}$, supporting the molecular formula of $\mathrm{C}_{27} \mathrm{H}_{39} \mathrm{O}_{7}$ (calcd for $\mathrm{C}_{27} \mathrm{H}_{40} \mathrm{O}_{7}$ 475.2696). An $\alpha, \beta$-unsaturated carbonyl functionality $\left(\delta_{\mathrm{C}} 200.8,164.7\right.$, and 126.2) similar to those of 4 and 5 was evident from the ${ }^{13} \mathrm{C}$ NMR spectrum of 13 . This system was attributed to $\mathrm{C}-5=\mathrm{C}-6-\mathrm{C}-7(=\mathrm{O})$ on the basis of the longrange $\mathrm{HMBC}$ correlations from $\mathrm{C}-5$ to $\mathrm{H}_{3}-19\left(\delta_{\mathrm{H}} 1.90\right)$ and from C-4/C-10 to H-6. Other distinguishing features observed for metabolite 13 were the presence of two oxygenated tertiary carbon resonances $\left(\delta_{\mathrm{C}} 79.0,86.5\right)$ in the ${ }^{13} \mathrm{C}$ NMR spectrum.
When the COSY and TOCSY spectra were inspected beginning from the $\mathrm{H}_{2}-12$ resonances $\left(\delta_{\mathrm{H}} 1.58\right.$ and 2.38$)$, the spin system $\mathrm{H}_{2}-12 \rightarrow \mathrm{H}_{2}-11\left(\delta_{\mathrm{H}} 2.47\right.$ and 3.25$) \rightarrow \mathrm{H}-9\left(\delta_{\mathrm{H}}\right.$ 3.18) was established, suggesting the first oxygenation at C-8 due to the absence of correlation between $\mathrm{H}-9$ and $\mathrm{H}-8$. Moreover, the long-range correlation from the carbon at $\delta_{\mathrm{C}}$ 79.0 to H-6 $\left(\delta_{\mathrm{H}} 6.12\right)$ confirmed oxygenation at C-8. The second hydroxy group was located at $\mathrm{C}-14$ as in $\mathbf{9}$ and $\mathbf{1 0}$ because of the significant $\mathrm{HMBC}$ from the carbon resonating at $\delta_{\mathrm{C}} 86.5$ signal to $\mathrm{H}_{3}-18\left(\delta_{\mathrm{H}} 1.74\right)$ and $\mathrm{H}_{2}-15\left(\delta_{\mathrm{H}} 2.71\right.$ and $3.42)$. The exchangeable proton of $\mathrm{C}-8(\mathrm{OH})\left(\delta_{\mathrm{H}} 7.41\right)$ showed ROESY cross-peaks with $\mathrm{H}_{3}-18$ and $\mathrm{H}_{3}-19$, revealing its $\beta$ orientation, whereas the $\mathrm{C}-14(\mathrm{OH})$ proton $\left(\delta_{\mathrm{H}} 4.92\right)$ had correlations with $\mathrm{H}-9 \quad\left(\begin{array}{lll}\delta_{\mathrm{H}} & 3.18\end{array}\right)$ and $\mathrm{H}-17 \quad\left(\begin{array}{ll}\delta_{\mathrm{H}} & 2.82\end{array}\right)$, substantiating its $\alpha$-orientation as in 9 and 10. Consequently, the structure of metabolite 13 was defined as spirosta-5,25(27)diene- $1 \beta, 3 \beta, 8 \beta, 14 \alpha$-tetraol-7-one.

In the HRMS spectrum of 14, a sodium adduct ion was observed at $\mathrm{m} / z$ 481.2575 $[\mathrm{M}+\mathrm{Na}]^{+}$(calcd 481.2566 for $\mathrm{C}_{27} \mathrm{H}_{38} \mathrm{O}_{6} \mathrm{Na}$ ), indicating a $30 \mathrm{amu}$ difference in comparison to 1. Inspection of the ${ }^{1} \mathrm{H}$ and ${ }^{13} \mathrm{C}$ NMR spectra of 14 suggested an $\alpha, \beta$-unsaturated carbonyl moiety as in $13\left(\delta_{\mathrm{C}} 165.3,128.4\right.$, and $\left.200.9 ; \delta_{\mathrm{H}-6} 6.02\right)$, which was also corroborated via key HMBC correlations. Examination of the ${ }^{13} \mathrm{C}$ and DEPT135 spectra indicated an additional carbon signal at $\delta_{\mathrm{C}} 84.5$. A longrange correlation between this carbon and $\mathrm{H}_{3}-18\left(\delta_{\mathrm{H}} 1.13\right)$ suggested oxygenation at $\mathrm{C}-14$ as in 9,10 , and 13 . Based on the ROESY correlations between $\mathrm{C}-14(\mathrm{OH})$ and $\mathrm{H}-16 / \mathrm{H}-9$, the hydroxy group was $\alpha$-oriented. Thus, the structure of 14 was elucidated as spirosta-5,25(27)-diene-1 $\beta, 3 \beta, 14 \alpha$-triol-7-one.

The molecular formula of 15 was found to be $\mathrm{C}_{27} \mathrm{H}_{40} \mathrm{O}_{6}$ based on the sodium adduct ion at $\mathrm{m} / z 483.2728[\mathrm{M}+\mathrm{Na}]^{+}$ (calcd for $\mathrm{C}_{27} \mathrm{H}_{40} \mathrm{O}_{6} \mathrm{Na} 483.2723$ ), indicating eight indices of hydrogen deficiency. In the low-field region of the ${ }^{1} \mathrm{H}$ and ${ }^{13} \mathrm{C}$ NMR spectra, the absence of characteristic resonances (C-5, C6 and H-6) derived from the olefinic system was noted. Based on the absence of unsaturation in $\mathbf{1 5}$, an additional ring system was proposed based on the identical hydrogen deficiency index compared to NR (1). The major spin systems were established by COSY and TOCSY spectra, which suggested modifications in rings $\mathrm{B}$ and $\mathrm{C}$. The oxygenation at $\mathrm{C}-14$ was readily inferred based on the ${ }^{3} J_{\mathrm{C}-\mathrm{H}}$ HMBC correlation between $\mathrm{C}-14$ and $\mathrm{H}_{3}$ $18\left(\delta_{\mathrm{H}} 1.04\right)$. In the COSY spectrum, the last spin system was tracked from the characteristic $\mathrm{H}_{2}-12\left(\delta_{\mathrm{H}} 1.36\right.$ and 2.33) to the oxymethine $\mathrm{H}-7$ resonance $\left(\delta_{\mathrm{H}} 4.75\right)$. The C-7 hydrogen also coupled with another low-field signal resonating at $\delta_{\mathrm{H}} 3.41$, readily assigned to $\mathrm{H}-6$, hence establishing the spin system from $\mathrm{H}_{2}-12$ to $\mathrm{H}-6$. In the COSY spectrum, $\mathrm{H}-7$ showed a correlation with an exchangeable proton at $\delta_{\mathrm{H}} 7.92$, confirming the second oxygenation position in the structure (Figure 3 ). The carbon observed at $\delta_{\mathrm{C}} 63.4$ was ascribed to $\mathrm{C}-5$ on the basis of its key HMBCs to $\mathrm{H}_{3}-19\left(\delta_{\mathrm{H}} 1.55\right)$ and $\mathrm{H}_{2}-4\left(\delta_{\mathrm{H}} 2.77\right.$, $2 \mathrm{H}, \mathrm{m})$. When the high-field shift of $\mathrm{C}-5$ was evaluated together with the remaining index of hydrogen deficiency, the presence of an epoxide moiety was evident between C-5 and C- $6 .^{31,32}$ Based on the NOESY cross-peaks between $\mathrm{H}-7$ and $\mathrm{H}-8 \beta / \mathrm{H}$ $15 \beta, \mathrm{C}-14(\mathrm{OH})\left(\delta_{\mathrm{H}} 5.61\right)$, and $\mathrm{H}-9 \alpha\left(\delta_{\mathrm{H}} 2.88\right)$ and the absence of correlation between HO-7 and HO-6, C-7 and C-14 (OH) were $\alpha$-cofacially oriented, whereas the epoxide $\operatorname{ring}$ had $\beta$ orientation. Thus, the structure of metabolite $\mathbf{1 5}$ was elucidated as $5 \beta(6)$-epoxyspirost-25(27)-ene-1 $\beta, 3 \beta, 7 \alpha, 14 \alpha$-tetraol.

The major steroidal sapogenins of Ruscus sp., neoruscogenin (1) and ruscogenin, are responsible for vasoconstrictive, 

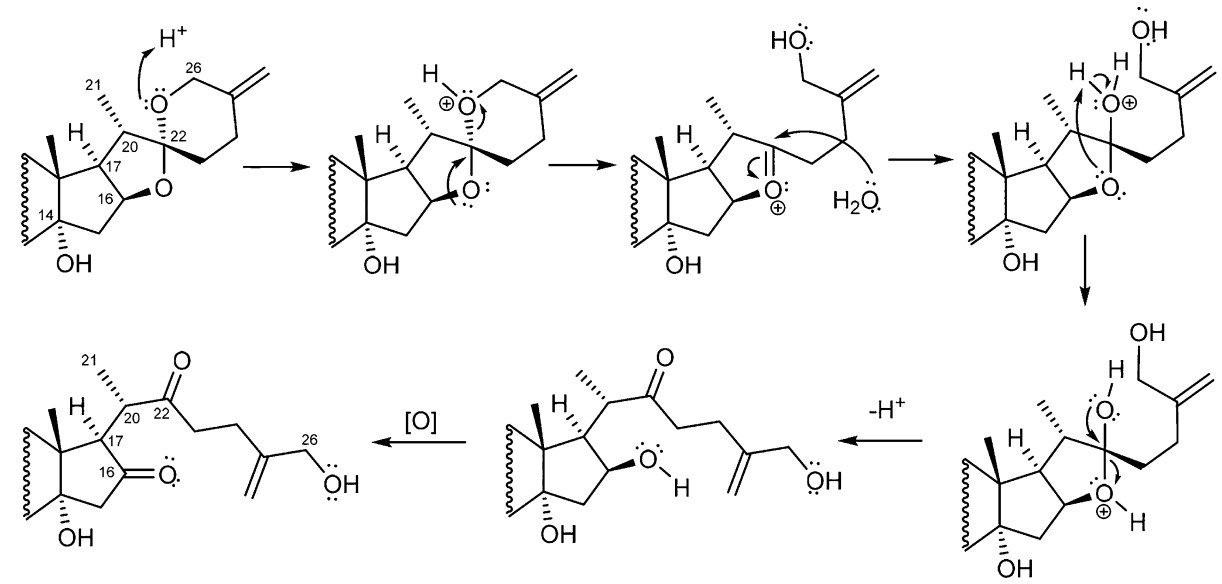

Figure 5. Putative mechanism of spiroketal ring cleavage to yield the cholestane-type framework.

venotonic, antithrombotic, and anti-inflammatory activity. ${ }^{18,19,23,33,34}$ The extracts of the underground part of Ruscus have been standardized to contain these spirostanol steroids as a mixture, in which neoruscogenin $(\mathbf{1})$ is the major constituent.

Microbial transformation has been widely used to obtain pharmacologically active steroids. It is advantageous in comparison to chemical synthesis due to its capability to perform stereo- and regioselective reactions at active and inactive sites of the substrate molecules. ${ }^{4,35-37}$ The recent studies have shown that endophytes can be used as biocatalysts due to their ability to catalyze diverse and unique reactions. $^{11-13,38,39}$

Our previous studies revealed the biotransformation capacity of the filamentous fungi, viz. Cunninghamella blakesleeana and Glomerella fusarioides, toward triterpenoids. ${ }^{40-42}$ In this study, we demonstrated the potential of an endophytic fungus ( $A$. eureka) as biocatalyst to transform the steroidal sapogenin neoruscogenin. As a result, 14 new metabolites were obtained, and their structures were elucidated. Metabolites 8-15 were mainly transformed via actions of CYP450 monooxygenase enzymes, resulting in oxygenation reactions (8-12 and 15), whereas subsequent dehydrogenation reactions provided carbonyl derivatives (13 and 14). As it was expected from the literature, the main oxygenation site was C-7 due to its allylic nature in the $\mathrm{B}$ ring. ${ }^{4,43,44}$ The other oxygenation location was C-14, which was shown to be subject to oxygenation as in previous studies with other fungi. ${ }^{45-47}$ Oxygenations at C-8, C-11, and C-12 were also observed. C-11 and $\mathrm{C}-12$ oxygenations are more common in steroid chemistry; however, $\mathrm{C}-8$ is at an encumbered position on the steroid skeleton, and modification of this stereocenter is rare due to steric hindrance. Based on the literature, only Alternaria alternata and Corynespora cassiicada CYP450s are capable of performing this unique oxygenation. ${ }^{48,49}$

The other striking reaction occurring in compound $\mathbf{1}$ was epoxidation at the $\Delta^{5(6)}$ olefinic bond to afford 15. Even though there are several reports of microbial ${ }^{50-53}$ or semisynthetic $^{54,55}$ epoxidation products of steroids, this is the first study demonstrating a $\Delta^{5(6)}$ epoxidation on a steroidal skeleton by a microbial enzyme system.

A spiroketal hydrolysis reaction of 1 afforded the acyclic side chain of metabolites 2-6 (Figure 5). Subsequently 2-6 are susceptible to further transformations on the acyclic/cholestane-type steroidal framework to give oxygenation, oxidation, acylation, migration, and dehydration products. Cleavage of the
C-22(O)C-26 oxygen bridge afforded a furostanol-type skeleton, and its modification resulted in the formation of a $\mathrm{C}-18(\mathrm{O}) \mathrm{C}-22$ epoxide ring system (7). These cleavages and further epoxide ring formation are reported for the first time in a microbial transformation study. In addition, a spiroketal hydrolysis reaction is important for the synthesis of potent cytotoxic metabolites under mild conditions, viz., the cholestane-type steroid OSW-1 $(3 \beta, 16 \beta, 17 \alpha$-trihydroxycholest-5-en-22-one $16-O-(2-O-4$-methoxybenzoyl- $\beta$-D-xylopyranosyl)-( $1 \rightarrow 3)$-(2-O-acetyl- $\alpha$-L-arabinopyranoside $)){ }^{56-59}$

In summary, the catalytic diversity of the endophytic fungus A. eureka is remarkable. These results prove the capability of endophytes for catalyzing novel reactions and warrant further studies to exploit their use in the field of natural product and bioorganic chemistry. Finally, as can be seen from the diversity of the metabolites, neoruscogenin (1), the major bioactive component of the Ruscus preparations, is subject to many biotransformation reactions, which might be taken into consideration for its conceivable mammalian metabolites, as well as its current or potential therapeutic use.

\section{EXPERIMENTAL SECTION}

General Experimental Procedures. Optical rotations were measured using a PerkinElmer 341 polarimeter. MS data were acquired on an Agilent 1200/6530 Instrument-HRTOFMS. 1D and 2D NMR spectra were obtained at $500 \mathrm{MHz}$ for ${ }^{1} \mathrm{H}$ and $125 \mathrm{MHz}$ for ${ }^{13} \mathrm{C}$ on a Bruker DRX 500 spectrometer, in pyridine- $d_{5}$, with solvent peaks used as references. Column chromatography experiments were carried out on silica gel 60 (40-63 $\mu \mathrm{m}$-Merck), Sephadex LH-20 (GE Healthcare), and RP $\left(\mathrm{C}_{18}, 25-40 \mu \mathrm{m}\right)$ (Merck). TLC analyses were carried out on silica gel 60 F254 (Merck) and RP-18 F254s (Merck) plates. HPTLC experiments were carried out on HPTLC silica gel 60 F254 (Merck). Compounds were detected by UV and $20 \%$ aqueous $\mathrm{H}_{2} \mathrm{SO}_{4}$ spraying reagent followed by heating at $105{ }^{\circ} \mathrm{C}$ for $1-2 \mathrm{~min}$.

Substrate. The substrate neoruscogenin was isolated and purified from Ruscus aculeatus L., donated by Bionorm Natural Products Production \& Marketing Corp., Menderes-Izmir, Turkey. Its purity was determined to be $95 \%$ by HPLC analysis.

Fungal Strain and Culture Media. The endophytic fungus Alternaria eureka was isolated from Astragalus angustifolius, collected in Manisa-Spil Mountain, Izmir, Turkey, in June 2013. It was identified based on DNA sequence analysis conducted by DSMZ (Leibniz Institute DSMZ-German Collection of Microorganisms and Cell Cultures). The original culture was deposited at the Erdal Bedir Laboratory with the deposit number 20131E1BL1. ${ }^{41}$ All cultures were maintained on potato dextrose agar (PDA) slants and stored at $4{ }^{\circ} \mathrm{C}$ 
until use. Prior to biotransformation, the fungus was precultivated on PDA in Petri dishes for $5-7$ days at $25{ }^{\circ} \mathrm{C}$

Microbial Transformation Procedures. The biotransformation process was conducted at two scales, analytical and preparative. Inoculum of $2 \%$ derived from the suspension of 5-7-day-old cultures with Tween $80(0.1 \%)$ was used in the biotransformation process. A one-stage fermentation protocol was followed, where 1 was fed to the media $72 \mathrm{~h}$ after the inoculation. The biotransformation media contained $2 \%$ glucose, $0.5 \%$ yeast extract, $0.5 \% \mathrm{NaCl}, 0.5 \% \mathrm{~K}_{2} \mathrm{HPO}_{4}$, and $0.5 \%(\mathrm{w} / \mathrm{v})$ peptone $(\mathrm{pH} 6.0)$. Analytical scale was conducted using $250 \mathrm{~mL}$ flasks containing $50 \mathrm{~mL}$ of media and $\mathbf{1}(10 \mathrm{mg})$. Every 2 days, samples with a volume of $0.5 \mathrm{~mL}$ were taken and centrifuged. The supernatants were extracted with EtOAc. In order to differentiate the transformed products from the metabolites of the microorganisms, one flask was kept under the same conditions but without lead compound. In preparative scale, 34 Erlenmeyer flasks each containing $200 \mathrm{~mL}$ of biotransformation media and $40 \mathrm{mg}$ of 1 were used at the same conditions as analytical scale $\left(25^{\circ} \mathrm{C}\right.$ and $\left.180 \mathrm{rpm}\right)$ for 10 days.

Extraction and Isolation. After the incubation period, prior to the extraction with EtOAc $(\times 3)$ and $n-\mathrm{BuOH}$, microorganisms were separated from the media by using a Buchner funnel. After drying over anhydrous $\mathrm{Na}_{2} \mathrm{SO}_{4}$, the organic layers were evaporated under reduced pressure. The EtOAc $(1.373 \mathrm{~g})$ and $n-\mathrm{BuOH}(1.253 \mathrm{~g})$ extracts were applied to Sephadex LH-20 column chromatography (CC) (100 g, 3.5 $\times 43 \mathrm{~cm}$ ) separately and eluted with $\mathrm{MeOH}$. The fractions from each column with NR metabolites, viz. 19-28 (1.157 g) and 19 and 20 $(284.9 \mathrm{mg})$, were pooled and subjected to reversed-phase silica gel $\left(\mathrm{C}_{18}, 70 \mathrm{~g}, 3.5 \times 26 \mathrm{~cm}\right)$ to yield 39 main fractions after elution with a $\mathrm{MeOH} / \mathrm{H}_{2} \mathrm{O}$ gradient $(30: 70100 \mathrm{~mL}, 35: 65100 \mathrm{~mL}, 40: 60100 \mathrm{~mL}$, 45:55 $100 \mathrm{~mL}, 50: 50300 \mathrm{~mL}, 55: 45200 \mathrm{~mL}, 60: 40200 \mathrm{~mL}, 70: 30$ $300 \mathrm{~mL}, 80: 20300 \mathrm{~mL}, 90: 10250 \mathrm{~mL}, 100: 0250 \mathrm{~mL})$. Fraction A (33.7 mg) was purified on silica gel open-column chromatography (8 g; $2 \times 9.5 \mathrm{~cm}$ ), eluting with $\mathrm{CHCl}_{3} / \mathrm{MeOH} / \mathrm{H}_{2} \mathrm{O}$ (90:10:0.5), to afford $3.5 \mathrm{mg}$ of 2 . In order to isolate metabolites $4(5.1 \mathrm{mg})$ and 7 $(4.6 \mathrm{mg})$, fraction B $(42.3 \mathrm{mg})$ was subjected to silica gel open-column chromatography $(12 \mathrm{~g} ; 2 \times 13 \mathrm{~cm})$ and eluted with $\mathrm{CHCl}_{3} / \mathrm{MeOH} /$ $\mathrm{H}_{2} \mathrm{O}$ (95:5:0.5). Fraction $\mathrm{C}(63.0 \mathrm{mg})$ was first purified on silica gel $\mathrm{CC}(15 \mathrm{~g}, 2 \times 14 \mathrm{~cm})$ with $\mathrm{CHCl}_{3} / \mathrm{MeOH} / \mathrm{H}_{2} \mathrm{O}(95: 5: 0.5)$ to give 6 $(1.5 \mathrm{mg})$. To isolate metabolite $3(0.5 \mathrm{mg})$, subfraction $\mathrm{C}$, C1 $(5.5$ $\mathrm{mg}$ ), was subjected to preparative TLC (HPTLC) eluting with $n$ hexane/EtOAc/MeOH (10:10:4). To purify metabolite 5, fraction D $(38 \mathrm{mg})$ was subjected to silica gel CC $(12 \mathrm{~g}, 1.5 \times 18 \mathrm{~cm})$ and eluted with $\mathrm{CHCl}_{3} / \mathrm{MeOH}(95: 5)$. Subfraction D1 (5.5 mg) was subjected to HPTLC using $\mathrm{CHCl}_{3} / \mathrm{MeOH} / \mathrm{H}_{2} \mathrm{O}$ (85:15:0.5). Fractions E and $\mathrm{F} 1$ containing the metabolite $10(9.4 \mathrm{mg})$ were separately subjected to silica gel CC. Fraction E (30 mg) was subjected to silica gel CC (10 g, $1.5 \times 15 \mathrm{~cm})$ and eluted with $\mathrm{CHCl}_{3} / \mathrm{MeOH} / \mathrm{H}_{2} \mathrm{O}$ (90:10:0.5). Fraction F1 $(36.3 \mathrm{mg})$, the supernatant of fraction F $(48.2 \mathrm{mg})$, was also subjected to silica gel $\mathrm{CC}(15 \mathrm{~g}, 1.5 \times 20 \mathrm{~cm})$ eluted with $\mathrm{CHCl}_{3} /$ $\mathrm{MeOH}$ (90:10) to which $0.2 \mu \mathrm{L}$ of HOAc was added for each $100 \mathrm{~mL}$. Eluting fraction $\mathrm{G}$ with cyclohexane/EtOAc/ $\mathrm{MeOH}(10: 10: 1)$ on silica gel CC $(8 \mathrm{~g}, 1.5 \times 12 \mathrm{~cm})$ afforded $8.0 \mathrm{mg}$ of metabolite 11 . With further purification of subfraction G (fraction G1) $(7.5 \mathrm{mg}$ ) on HPTLC with $\mathrm{CHCl}_{3} / \mathrm{MeOH} / \mathrm{H}_{2} \mathrm{O}$ (90:10:0.5), $3.0 \mathrm{mg}$ of metabolite 13 was obtained. Fraction $\mathrm{H}(30.5 \mathrm{mg})$ was subjected to normal-phase silica gel CC $(10 \mathrm{~g}, 1.5 \times 15)$ eluted with $\mathrm{CHCl}_{3} / \mathrm{MeOH}(97: 3)$ to give metabolites $12(0.5 \mathrm{mg})$ and $\mathbf{1 5}(2.0 \mathrm{mg})$. Fractions I $(55.0 \mathrm{mg})$ and $\mathrm{J}(32.0 \mathrm{mg})$ on precipitation with $\mathrm{MeOH}$ gave metabolites 14 (7.0 $\mathrm{mg})$ and $8(7.3 \mathrm{mg})$, respectively.

Cholesta-5,25(27)-diene-1 $\beta, 3 \beta, 7 \beta, 14 \alpha, 26$-pentaol-16,22-dione (2): white, amorphous solid; $[\alpha]^{25}-48(c 0.1, \mathrm{MeOH}) ;{ }^{12} \mathrm{H}$ NMR data (pyridine- $d_{5}, 500 \mathrm{MHz}$ ) see Table $1 ;{ }^{13} \mathrm{C}$ NMR data (pyridine- $d_{5}$, $125 \mathrm{MHz}$ ) see Table 1; HRESIMS (positive ion mode) $\mathrm{m} / z 499.2653$ $[\mathrm{M}+\mathrm{Na}]^{+}$(calcd 499.2671 for $\left.\mathrm{C}_{27} \mathrm{H}_{40} \mathrm{O}_{7} \mathrm{Na}\right)$.

Cholesta-5,25(27)-diene-1 $\beta, 3 \beta, 7 \alpha, 14 \alpha, 26$-pentaol-16,22-dione (3): white, amorphous solid; $[\alpha]_{\mathrm{D}}^{25}-192(c 0.02, \mathrm{MeOH}) ;{ }^{1} \mathrm{H}$ NMR data (pyridine- $d_{5}, 500 \mathrm{MHz}$ ) see Table $1 ;{ }^{13} \mathrm{C}$ NMR data (pyridine- $d_{5}$, $125 \mathrm{MHz}$ ) see Table 1; HRESIMS (positive ion mode) $\mathrm{m} / z 499.2656$ $[\mathrm{M}+\mathrm{Na}]^{+}\left(\right.$calcd 499.2672 for $\left.\mathrm{C}_{27} \mathrm{H}_{40} \mathrm{O}_{7} \mathrm{Na}\right)$.
Cholesta-5,25(27)-diene-1 $\beta, 3 \beta, 14 \alpha, 26$-tetraol-7,16,22-trione (4): white, amorphous solid; $[\alpha]_{\mathrm{D}}^{25}-21(c 1, \mathrm{MeOH}) ;{ }^{1} \mathrm{H}$ NMR data (pyridine- $d_{5}, 500 \mathrm{MHz}$ ) see Table $1 ;{ }^{13} \mathrm{C}$ NMR data (pyridine- $d_{5}, 125$ $\mathrm{MHz}$ ) see Table 1 ; HRESIMS (positive ion mode) $\mathrm{m} / \mathrm{z} 497.2532$ (calcd for $\mathrm{C}_{27} \mathrm{H}_{38} \mathrm{O}_{7} \mathrm{Na}$ 497.2512).

26-O-Acetylcholesta-5,25(27)-diene-1 $\beta, 3 \beta, 14 \alpha, 26$-tetraol7,16,22-trione (5): white, amorphous solid; $[\alpha]^{25}{ }_{\mathrm{D}}-191$ (c 0.03 , $\mathrm{MeOH}) ;{ }^{1} \mathrm{H}$ NMR data (pyridine- $d_{5}, 500 \mathrm{MHz}$ ) see Table $1 ;{ }^{13} \mathrm{C}$ NMR data (pyridine- $d_{5}, 125 \mathrm{MHz}$ ) see Table 1; HRESIMS (positive ion mode) $\mathrm{m} / z 555.2377[\mathrm{M}+\mathrm{K}]^{+}\left(\right.$calcd for $\left.555.2360 \mathrm{C}_{29} \mathrm{H}_{40} 0_{8} \mathrm{~K}\right)$.

Cholesta-4,6,25(27)-triene-1 $\beta, 14 \alpha, 26$-triol-3,16,22-trione (6): white, amorphous solid; $[\alpha]^{25}-121(c 0.1 \mathrm{MeOH}) ;{ }^{1} \mathrm{H}$ NMR data (pyridine- $d_{5}, 500 \mathrm{MHz}$ ) see Table $1 ;{ }^{13} \mathrm{C}$ NMR data (pyridine- $d_{5}, 125$ MHz) see Table 1; HRESIMS (positive ion mode) $\mathrm{m} / z$ 479.2403 [M $+\mathrm{Na}]^{+}\left(\right.$calcd 479.2410 for $\left.\mathrm{C}_{27} \mathrm{H}_{36} \mathrm{O}_{6} \mathrm{Na}\right)$.

18(22)-Epoxyfurosta-5,25(27)-diene-1 $\beta, 3 \beta, 7 \alpha, 26$-tetraol (7): white, amorphous solid; $[\alpha]_{\mathrm{D}}^{25}-46(c 0.1, \mathrm{MeOH}) ;{ }^{1} \mathrm{H}$ NMR data (pyridine- $d_{5}, 500 \mathrm{MHz}$ ) see Table $2 ;{ }^{13} \mathrm{C}$ NMR data (pyridine- $d_{5}, 125$ $\mathrm{MHz}$ ) see Table 2; HRESIMS (positive ion mode) $\mathrm{m} / \mathrm{z} 483.2784$ [M $+\mathrm{Na}]^{+}$(calcd for $\mathrm{C}_{27} \mathrm{H}_{40} \mathrm{O}_{6} \mathrm{Na} 483.2723$ ).

Spirosta-5,25(27)-diene-1 $\beta, 3 \beta, 7 \beta$-triol (8): white, amorphous solid; $[\alpha]_{\mathrm{D}}^{25}-126(c 0.1, \mathrm{MeOH}) ;{ }^{1} \mathrm{H}$ NMR data (pyridine- $\left.d_{5}, 500 \mathrm{MHz}\right)$ see Table $2 ;{ }^{13} \mathrm{C}$ NMR data (pyridine- $d_{5}, 125 \mathrm{MHz}$ ) see Table 2; HRESIMS (positive ion mode) $\mathrm{m} / z 445.2956[\mathrm{M}+\mathrm{H}]^{+}$(calcd for $\mathrm{C}_{27} \mathrm{H}_{41} \mathrm{O}_{5}$ 445.2954).

Spirosta-5,25(27)-diene-1 $\beta, 3 \beta, 7 \alpha, 14 \alpha$-tetraol (9): white, amorphous solid; $[\alpha]_{\mathrm{D}}^{25}-113(c 0.1, \mathrm{MeOH}) ;{ }^{1} \mathrm{H}$ NMR data (pyridine$d_{5}, 500 \mathrm{MHz}$ ) see Table $2 ;{ }^{13} \mathrm{C}$ NMR data (pyridine- $d_{5}, 125 \mathrm{MHz}$ ) see Table 2; HRESIMS (positive ion mode) $\mathrm{m} / z 483.2733[\mathrm{M}+\mathrm{Na}]^{+}$ (calcd for $\mathrm{C}_{27} \mathrm{H}_{40} \mathrm{O}_{6} \mathrm{Na} 483.2723$ ).

Spirosta-5,25(27)-diene-1 $\beta, 3 \beta, 7 \alpha, 12 \beta, 14 \alpha$-pentaol (10): white, amorphous solid; $[\alpha]^{25}-68(c \quad 0.1, \mathrm{MeOH}) ;{ }^{1} \mathrm{H}$ NMR data (pyridine- $d_{5}, 500 \mathrm{MHz}$ ) see Table $2 ;{ }^{13} \mathrm{C}$ NMR data (pyridine- $d_{5}$, $125 \mathrm{MHz}$ ) see Table 2; HRESIMS (positive ion mode) $\mathrm{m} / z 477.2848$ $[\mathrm{M}+\mathrm{H}]^{+}$(calcd for $\left.\mathrm{C}_{27} \mathrm{H}_{41} \mathrm{O}_{7} 477.2852\right)$.

Spirosta-5,25(27)diene-1 $\beta, 3 \beta, 7 \alpha, 12 \beta$-tetraol (11): white, amorphous solid; $[\alpha]_{\mathrm{D}}^{25}-161(c 0.03, \mathrm{MeOH}) ;{ }^{1} \mathrm{H}$ NMR data (pyridine$d_{5}, 500 \mathrm{MHz}$ ) see Table $2 ;{ }^{13} \mathrm{C}$ NMR data (pyridine- $d_{5}, 125 \mathrm{MHz}$ ) see Table 2; HRESIMS (positive ion mode) $\mathrm{m} / z$ 461.2904 $[\mathrm{M}+\mathrm{H}]^{+}$ (calcd for $\mathrm{C}_{27} \mathrm{H}_{41} \mathrm{O}_{6}$ 461. 2903).

Spirosta-5,25(27)-diene-1 $\beta, 3 \beta, 7 \alpha, 11 \alpha$-tetraol (12): white, amorphous solid; $[\alpha]^{25}-177(c 0.03, \mathrm{MeOH}) ;{ }^{1} \mathrm{H}$ NMR data (pyridine$d_{5}, 500 \mathrm{MHz}$ ) see Table $3 ;{ }^{13} \mathrm{C}$ NMR data (pyridine- $d_{5}, 125 \mathrm{MHz}$ ) see Table 3; HRESIMS (positive ion mode) $\mathrm{m} / z 461.2901[\mathrm{M}+\mathrm{H}]^{+}$ (calcd for $\mathrm{C}_{27} \mathrm{H}_{41} \mathrm{O}_{6} 461.2903$ ).

Spirosta-5,25(27)-diene-1 $\beta, 3 \beta, 8 \beta, 14 \alpha$-tetraol-7-one (13): white, amorphous solid; $[\alpha]_{\mathrm{D}}^{25}-75(c \quad 0.04, \mathrm{MeOH}) ;{ }^{1} \mathrm{H}$ NMR data (pyridine- $d_{5}, 500 \mathrm{MHz}$ ) see Table $3 ;{ }^{13} \mathrm{C}$ NMR data (pyridine- $d_{5}, 125$ $\mathrm{MHz}$ ) see Table 3; HRESIMS (positive ion mode) $\mathrm{m} / z$ 475.2704 [M $+\mathrm{H}]^{+}$(calcd for $\mathrm{C}_{27} \mathrm{H}_{39} \mathrm{O}_{7} 475.2696$ ).

Spirosta-5,25(27)-diene-1 $\beta, 3 \beta, 14 \alpha$-triol-7-one (14): white, amorphous solid; $[\alpha]_{\mathrm{D}}^{25}-212(c 0.03, \mathrm{MeOH}) ;{ }^{1} \mathrm{H}$ NMR data (pyridine$d_{5}, 500 \mathrm{MHz}$ ) see Table $3 ;{ }^{13} \mathrm{C}$ NMR data (pyridine- $d_{5}, 125 \mathrm{MHz}$ ) see Table 3; HRESIMS (positive ion mode) $\mathrm{m} / z$ 481.2575 $[\mathrm{M}+\mathrm{Na}]^{+}$ (calcd for $\mathrm{C}_{27} \mathrm{H}_{38} \mathrm{O}_{6} \mathrm{Na} 481.2566$ ).

$5 \beta(6)$-Epoxyspirosta-5,25(27)diene- $1 \beta, 3 \beta, 7 \alpha, 14 \alpha$-tetraol (15): white, amorphous solid; $[\alpha]_{\mathrm{D}}^{25}-23(c 0.1, \mathrm{MeOH}) ;{ }^{1} \mathrm{H}$ NMR data (pyridine- $d_{5}, 500 \mathrm{MHz}$ ) see Table $3 ;{ }^{13} \mathrm{C}$ NMR data (pyridine- $d_{5}, 125$ $\mathrm{MHz}$ ) see Table 3; HRESIMS (positive ion mode) $\mathrm{m} / z$ 483.2728 [M $+\mathrm{Na}]^{+}$(calcd for $\mathrm{C}_{27} \mathrm{H}_{40} \mathrm{O}_{6} \mathrm{Na} 483.272$ ).

\section{ASSOCIATED CONTENT}

\section{Supporting Information}

The Supporting Information is available free of charge on the ACS Publications website at DOI: 10.1021/acs.jnatprod.7b00898.

HRESIMS and ${ }^{1} \mathrm{H},{ }^{13} \mathrm{C}$, and $2 \mathrm{D}$ NMR spectra of compounds 2-15 (PDF) 


\section{AUTHOR INFORMATION}

\section{Corresponding Author}

*E-mail: erdalbedir@iyte.edu.tr.

\section{ORCID $\odot$}

Erdal Bedir: 0000-0003-1262-063X

\section{Notes}

The authors declare no competing financial interest.

\section{ACKNOWLEDGMENTS}

This project was supported by Ege University Scientific Research Project 15ECZ011 and partly by TUBITAK (Project No: 114Z958). We are very grateful to Bionorm Natural Products for providing neoruscogenin, and special thanks to NMR operator Anzarulhaque Anwarulhaque of Prince Sattam bin Abdulaziz University, Al-Kharj, Saudi Arabia.

\section{REFERENCES}

(1) Borges, K. B.; Borges, W. d. S.; Duran-Patron, R; Pupo, M. T.; Bonato, P. S.; Collado, I. G. Tetrahedron: Asymmetry 2009, 20, 385397.

(2) Fura, A.; Shu, Y.-Z.; Zhu, M.; Hanson, R. L.; Roongta, V.; Humphreys, W. G. J. Med. Chem. 2004, 47, 4339-4351.

(3) Carballeira, J. D.; Quezada, M. A.; Hoyos, P.; Simeó, Y.; Hernaiz, M. J.; Alcantara, A. R.; Sinisterra, J. V. Biotechnol. Adv. 2009, 27, 686714.

(4) Donova, M. V.; Egorova, O. V., Appl. Microbiol. Biotechnol.2012, 94 (6), 1423-1447.

(5) Smith, R. V.; Rosazza, J. P. J. Nat. Prod. 1983, 46 (1), 79-91.

(6) Murphy, C. D. Biotechnol. Lett. 2015, 37 (1), 19-28.

(7) Petrini, O. Fungal Endophytes of Tree Leaves. In Microbial Ecology of Leaves; Andrews, J. H.; Hirano, S. S., Eds.; Springer: New York, NY, 1991; pp 179-197.

(8) Wilson, D. Oikos 1995, 73, 274-276.

(9) Tan, R. X.; Zou, W. X. Nat. Prod. Rep. 2001, 18, 448-59.

(10) Kumar, A.; Ahmad, A. Biocatal. Biotransform. 2013, 31, 89-93.

(11) Prado, S.; Buisson, D.; Ndoye, I.; Vallet, M.; Nay, B. Tetrahedron Lett. 2013, 54, 1189-1191.

(12) Gaur, R.; Tiwari, S.; Jakhmola, A.; Thakur, J. P.; Verma, R. K.; Pandey, R.; Bhakuni, R. S. J. Mol. Catal. B: Enzym. 2014, 106, 46-55.

(13) Ying, Y.-M.; Shan, W.-G.; Zhan, Z.-J. J. Nat. Prod. 2014, 77 (9), 2054-2059.

(14) Warley de, S. B.; Keyller, B. B.; Pierina, S. B.; Suraia, S.; Monica,

T. P. Curr. Org. Chem. 2009, 13, 1137-1163.

(15) Fu, S.-b.; Yang, J.-s.; Cui, J.-l.; Feng, X.; Sun, D.-a. Chem. Pharm. Bull. 2011, 59, 1180-1182.

(16) Marcelon, G.; Verbeuren, T. J.; Lauressergues, H.; Vanhoutte, P. M. Gen. Pharmacol. 1983, 14, 103-106.

(17) Bouskela, E.; Cyrino, F. Z. G. A.; Marcelon, G. J. Cardiovasc. Pharmacol. 1993, 22, 221-224.

(18) Bouskela, E.; Cyrino, F. Z. G. A.; Marcelon, G. J. Cardiovasc. Pharmacol. 1994, 24, 281-285.

(19) Bouskela, E.; Cyrino, F. Z. G. A.; Marcelon, G. J. Cardiovasc. Pharmacol. 1994, 24, 165-170.

(20) Redman, D. A. J. Altern. Complement. Med. 2000, 6, 539-49.

(21) Vanscheidt, W.; Jost, V.; Wolna, P.; Lücker, P. W.; Müller, A.; Theurer, C.; Patz, B.; Grützner, K. I. Arzneim. Forsch. 2002, 52, $243-$ 250.

(22) Aguilar Peralta, G. R.; Arevalo Gardoqui, J.; Llamas Macias, F. J.; Navarro Ceja, V. H.; Mendoza Cisneros, S. A.; Martinez Macias, C. G. Int. Angiol. 2007, 26, 378-84.

(23) Balica, G.; Vostinaru, O.; Tamas, M.; Crisan, G.; Mogosan, C. J. Food. Agric. Environ. 2013, 11, 106-108.

(24) Kakkos, S. K.; Allaert, F. A. Int. Angiol. 2017, 36, 93-106.

(25) EMEA. Assessment Report on Ruscus aculeatus L., rhizoma; EMEA: London, 2008.
(26) ESCOP. Rusci rhizoma Butcher's Broom, 2nd ed.; Thieme: Stuttgart, 2003.

(27) Ni, Y.; Kim, H.-S.; William, K.; Kisic, W. A.; Schroepfer, G. J. Tetrahedron Lett. 1993, 34, 3687-3690.

(28) Huang, Y.-L.; Kou, J.-P.; Liu, J.-H.; Liu, N.; Yu, B.-Y. Drug Dev. Res. 2008, 69, 196-202.

(29) Chen, N. D.; Zhang, J.; Liu, J. H.; Yu, B. Y. Appl. Microbiol. Biotechnol. 2010, 86, 491-497.

(30) Chen, N.-D.; Yue, L.; Zhang, J.; Kou, J.-P.; Yu, B.-Y. Bioorg. Med. Chem. Lett. 2010, 20, 4015-4017.

(31) Poza, J. J.; Jiménez, C.; Rodriguez, J. Eur. J. Org. Chem. 2008, 2008, 3960-3969.

(32) Alarcón-Manjarrez, C.; Vargas-Romero, K.; González-Cruz, T. L.; Flores-Alamo, M.; Iglesias-Arteaga, M. A. J. Chem. Crystallogr. 2016, 46, 155-161.

(33) Lin, Y. N.; Jia, R.; Liu, Y. H.; Gao, Y.; Wang, L. L.; Kou, J. P.; Yu, B. Y. J. Steroid Biochem. Mol. Biol. 2015, 154, 85-93.

(34) Huang, Y. L.; Kou, J. P.; Ma, L.; Song, J. X.; Yu, B. Y. J. Pharmacol. Sci. 2008, 108 (2), 198-205.

(35) Kozlowska, E.; Urbaniak, M.; Kancelista, A.; Dymarska, M.; Kostrzewa-Suslow, E.; Stepien, L.; Janeczko, T. RSC Adv. 2017, 7, 31493-31501.

(36) Swizdor, A.; Panek, A.; Milecka-Tronina, N. Chem. Biol. Drug Des. 2016, 88, 844-849.

(37) Nassiri-Koopaei, N.; Faramarzi, M. A. Biocatal. Biotransform. 2015, 33, 1-28.

(38) Li, H.; Li, Z.; Ruan, G.; Yu, Y.; Liu, X. Biochem. Biophys. Res. Commun. 2016, 473, 874-878.

(39) Gonda, S.; Kiss-Szikszai, A.; Szucs, Z.; Balla, B.; Vasas, G. E. Int. Biodeterior. Biodegrad. 2016, 108, 115-121.

(40) Bedir, E.; Kula, C.; Oner, O.; Altas, M.; Tag, O.; Ongen, G. J. Mol. Catal. B: Enzym. 2015, 115, 29-34.

(41) Ekiz, G. Ph.D. Thesis; Ege University, Izmir, 2016.

(42) Kuban, M.; Ongen, G.; Bedir, E. Org. Lett. 2010, 12, 42524255 .

(43) Xu, M.; Huo, X. K.; Tian, X. G.; Dong, P. P.; Wang, C.; Huang, S. S.; Zhang, B. J.; Zhang, H. L.; Deng, S.; Ma, X. C. RSC Adv. 2015, 5, 78081-78089.

(44) Dong, T.; Wu, G. W.; Wang, X. N.; Gao, J. M.; Chen, J. G.; Lee, S. S. J. Mol. Catal. B: Enzym. 2010, 67, 251-256.

(45) Janeczko, T.; Dmochowska-Gladysz, J.; Kostrzewa-Suslow, E.; Bialonska, A.; Ciunik, Z. Steroids 2009, 74, 657-661.

(46) Faramarzi, M. A.; Badiee, M.; Yazdi, M. T.; Amini, M.; Torshabi, M. J. Mol. Catal. B: Enzym. 2008, 50, 7-12.

(47) Lamm, A. S.; Chen, A. R. M.; Reynolds, W. F.; Reese, P. B. Steroids 2007, 72, 713-722.

(48) Hunter, A. C.; Rymer, S.-J.; Dedi, C.; Dodd, H. T.; Nwozor, Q. C.; Moghimi, S. M. Biochim. Biophys. Acta, Mol. Cell Biol. Lipids 2011, 1811, 1054-1061.

(49) Liu, J.; Tang, W.; Chen, R.; Dai, J. Chem. Biodiversity 2015, 12, $1871-1880$

(50) Holland, H. L.; Chenchaiah, P. C.; Thomas, E. M.; Mader, B.; Dennis, M. J. Can. J. Chem. 1984, 62, 2740-2747.

(51) Holland, H. L.; Riemland, E. Can. J. Chem. 1985, 63, 11211126.

(52) Kang, H. K.; Lee, S. S. Arch. Pharmacal Res. 1997, 20, 525-528.

(53) Janeczko, T.; Świzdor, A.; Dmochowska-Gładysz, J.; Białońska, A.; Ciunik, Z.; Kostrzewa-Susłow, E. J. Mol. Catal. B: Enzym. 2012, 82, $24-31$.

(54) Kesavan, V.; Chandrasekaran, S. J. Org. Chem. 1998, 63, 69997001.

(55) Yang, D.; Jiao, G. S. Chem. - Eur. J. 2000, 6, 3517-3521.

(56) Alessandrini, L.; Ciuffreda, P.; Santaniello, E.; Terraneo, G. Steroids 2004, 69, 789-794.

(57) Xu, Q. H.; Peng, X. W.; Tian, W. S. Tetrahedron Lett. 2003, 44, 9375-9377.

(58) Fernández-Herrera, M. A.; López-Muñoz, H.; HernándezVázquez, J. M. V.; López-Dávila, M.; Escobar-Sánchez, M. L.; Sánchez- 
Sánchez, L.; Pinto, B. M.; Sandoval-Ramírez, J. Bioorg. Med. Chem. 2010, 18, 2474-2484.

(59) Guo, C.; LaCour, T. G.; Fuchs, P. L. Bioorg. Med. Chem. Lett. 1999, 9 (3), 419-424. 